\title{
SMEAR Estonia: Perspectives of a large-scale forest ecosystem - atmosphere research infrastructure
}

\author{
Steffen M. Noe ${ }^{1,{ }^{*}}$, Ülo Niinemets ${ }^{1,2}$, Alisa Krasnova ${ }^{1}$, \\ Dmitrii Krasnov $^{1}$, Azimeh Motallebi ${ }^{3}$, Vivika Kängsepp ${ }^{3}$, \\ Kalev Jõgiste ${ }^{3}$, Urmas Hõrrak ${ }^{4}$, Kaupo Komsaare ${ }^{4}$, \\ Sander Mirme ${ }^{4}$, Marko Vana ${ }^{4}$, Hannes Tammet ${ }^{4}$, \\ Jaana Bäck ${ }^{5}$, Timo Vesala ${ }^{6}$, Markku Kulmala ${ }^{6}$, \\ Tuukka Petäjä ${ }^{6}$ and Ahto Kangur ${ }^{3}$
}

\begin{abstract}
Noe, S.M., Niinemets, Ü., Krasnova, A., Krasnov, D., Motallebi, A., Kängsepp, V., Jõgiste, K., Hõrrak, U., Komsaare, K., Mirme, S., Vana, M., Tammet, H., Bäck, J., Vesala, T., Kulmala, M., Petäjä, T., Kangur, A. 2015. SMEAR Estonia: Perspectives of a large-scale forest ecosystem - atmosphere research infrastructure. - Forestry Studies | Metsanduslikud Uurimused 63, 56-84. ISSN 1406-9954. Journal homepage: http:// mi.emu.ee/forestry.studies
\end{abstract}

\begin{abstract}
Establishment of the SMEAR Estonia at a hemiboreal mixed deciduous broad-leaved-evergreen needle-leaved forest at Järvselja, South-Eastern Estonia, has strongly enhanced the possibilities for national and international cooperation in the fields of forest ecosystem - atmosphere research and impacts of climatic changes on forest ecosystems, atmospheric trace gases, aerosols and air ions. The station provides a multitude of comprehensive continuously measured data covering key climatic and atmospheric characteristics (state and dynamics of solar radiation, trace gases, aerosols and air ions, meteorological parameters) and forest ecosystem traits (net primary productivity, individual tree growth, gas-exchange characteristics, soil variables). The station follows a multidisciplinary and multiscale approach covering processes in spatial dimensions ranging from nanometres to several hundred square kilometres, being thus able to significantly contribute to worldwide measurement networks and the SMEAR network. Here we present an overview of the station, its data produced and we envision future developments towards sustainable research and development of the large-scale scientific infrastructure SMEAR Estonia.
\end{abstract}

Key words: Forest ecosystem and atmosphere measurements, SMEAR station, atmospheric aerosols and air ions, continuous observations.

Authors' address: ${ }^{1}$ Institute of Agricultural and Environmental Sciences, Estonian University of Life Sciences, 51014 Tartu, Estonia; ${ }^{2}$ Estonian Academy of Sciences, Kohtu 6, 10130 Tallinn, Estonia; ${ }^{3}$ Institute of Forestry and Rural Engineering, Estonian University of Life Sciences, Kreutzwaldi 1, 51014 Tartu, Estonia; ${ }^{4}$ Institute of Physics, University of Tartu, 18 Ülikooli Street, 50090 Tartu, Estonia; ${ }^{5}$ Department of Forest Sciences, P.O. Box 64, FI-00014 University of Helsinki, Finland; ' ${ }^{6}$ Division of Atmospheric Sciences, Department of Physics, P.O. Box 64, FI-00014 University of Helsinki, Finland; *e-mail: steffen.noe@emu.ee

\section{Introduction}

Long-term field measurements are of crucial importance for monitoring environmental change and effects of environmen- tal change on ecosystems and the feedback impact of these modifications on climate change (Kratz et al., 2003; Magill et al., 2004; Hari \& Kulmala, 2005; Hari et al., 2009). Although the continuous observa- 
tions are considered important, only few sites worldwide have long-term data on ecosystem-level measurements for more than 10 years (Kratz et al., 2003; Hari et al., 2009). Furthermore, the limitation of many sites is that only certain characteristics are monitored, e.g. most frequently ecosystemlevel $\mathrm{CO}_{2}$ and $\mathrm{H}_{2} \mathrm{O}$ fluxes are gauged, and very few stations have continuous records of other atmospheric constituents, including trace gases and aerosol particles (Hari \& Kulmala, 2005; Nieminen et al., 2014). Comprehensive measurements of forest ecosystem and atmospheric chemical-physical characteristics in their mutual relationship constitute the focus of SMEAR type stations (Station for Measuring EcosystemAtmosphere Relations, (Hari \& Kulmala, 2005; Hari et al., 2009, 2015)) in Finland (https://www.atm.helsinki.fi/SMEAR) and Estonia (http:/ / smear.emu.ee).

Apart from ecosystem-level flux measurements, gaining an insight into the processes controlling ecosystem dynamics requires detailed measurements at various ecosystem compartments to separate their influences on the components of ecosystem exchange and assess their responses to modifications in environmental drivers. Further, comprehensive long-term datasets are needed to allow for modelling of Earth system functioning on multiscale platforms and to be able to answer grand challenges according to climate change, increasing population, need of energy resources and food, air quality, land use change, transport and urbanisation apparent already now (Kulmala et al., 2015).

The aim of this paper is to provide a description of Station for Measuring Ecosystem-Atmosphere Relations (SMEAR Estonia) infrastructure. To show the potentials of the station, multiple samples of the results from ongoing long-term observations are also shown.

The work towards the SMEAR site establishment started in 2008 when an intensive and integrated measurement campaign combining flux, trace gas concentration, aerosol particles and plant and soil measurements were carried out in Järvselja; this campaign provided the first estimates of forest productivity by eddy covariance measurements in Estonia (Noe et al., 2011). Until the year 2013, these measurements were performed during intensive campaigns that led to several publications based on the collected data (Noe et al., 2012; Niinemets et al., 2013; Bourtsoukidis et al., 2014; Smolander et al., 2014). The campaigns were organized such that each provided new data eventually to cover the whole annual cycle. From 2013 on, an increasing amount of observations were performed continuously enabling preparation of longer datasets. These longer datasets are decisive in providing input to deeper scientific understanding on long-term changes of the hemiboreal environment to the policy makers and stakeholders at national and international levels, thereby starting to fulfil one of the main targets of functioning of the SMEAR platform as a whole.

\section{Description of the SMEAR Estonia measurement station}

The concept of the SMEAR Estonia station Initially, the basic concept of a SMEAR station introduced by professors Vesala, Hari and Kulmala was to measure the concentrations and fluxes of energy and matter at ecosystem scale for boreal forest ecosystems (Vesala et al., 1998; Hari \& Kulmala, 2005). Because the SMEAR Estonia station is located in the southern transition zone of the boreal biome we had to introduce some modifications in the original concept. In boreal ecosystems covered by Finnish SMEAR stations, the vegetation includes two clearly separated layers, overstory and understory (Figure 1). The most prominent conceptual change that guided positioning of instruments and conduction of measurements was the introduction of at least one more tree canopy layer. This reflects the greater tree species diversity colonizing different 


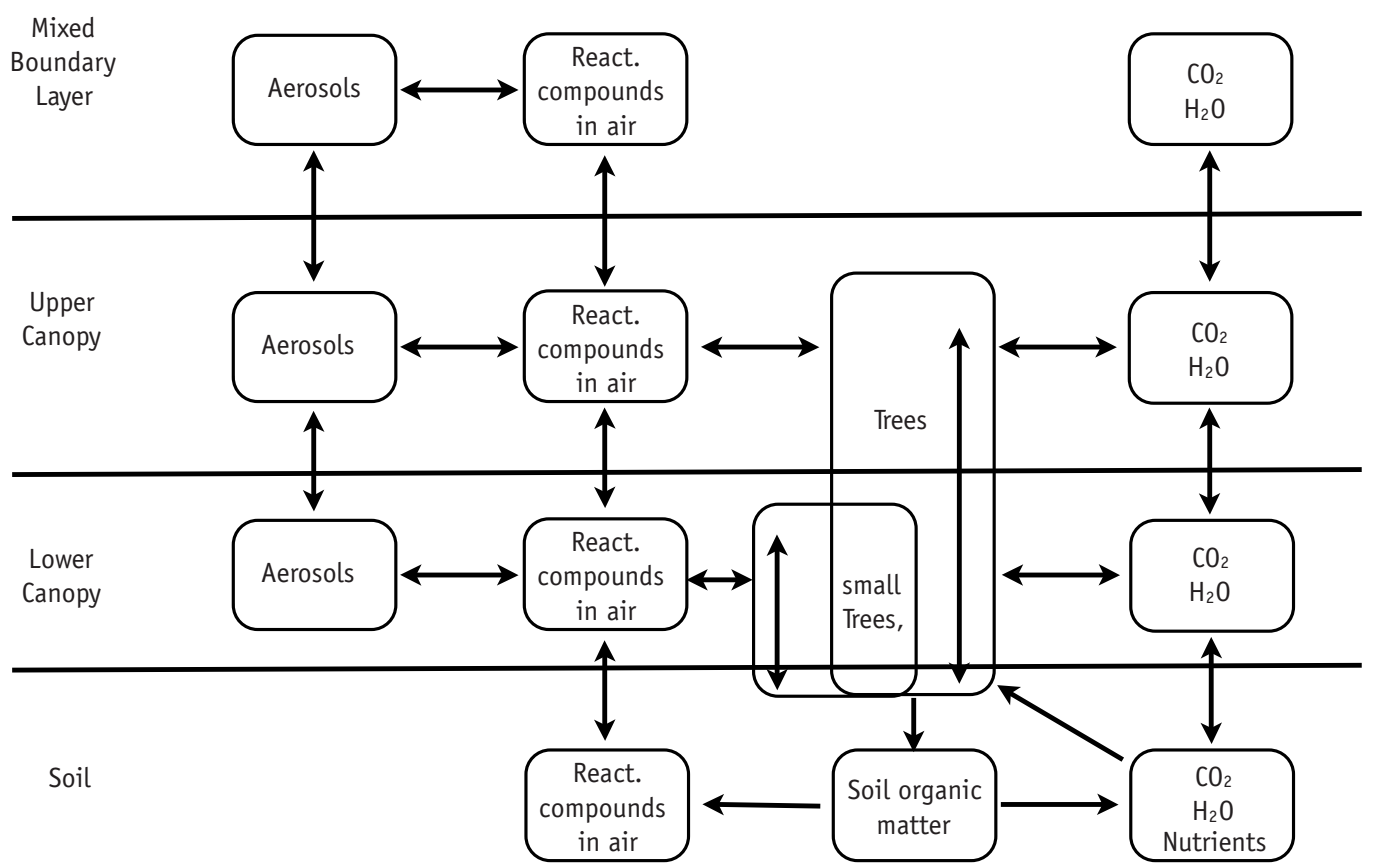

Figure 1. A schematic representation of the SMEAR Estonia concept (modified after Hari \& Kulmala (2005)). The boxes denote "reservoirs" of matter and the arrows denote processes that change the contents of these reservoirs (fluxes in some cases). The system is strongly interlinked and has many feedback loops leading to complex behaviour. Measurements are conducted in the mixed boundary layer of the free atmosphere, within the tree canopy on several heights and in the soil.

Joonis 1. SMEAR Eesti mõõtmispõhimõtete skemaatiline joonis Hari \& Kulmala (2005) järgi. Kastid viitavad mõõtmistega seotud mateeriale ning nooled mateeriat muutvatele ja mõõtejaamas mõõdetavatele protsessidele. Kõik süsteemi osad on protsesside tagasimõjude kaudu omavahel vahetult seotud ühtselt toimivaks ja mõõdetavaks kompleksseks tervikuks. Mõõtmised tehakse nii maapinna lähedases atmosfääris, erinevatel kõrgustel puistus kui ka mullas.

canopy and subcanopy layers in hemiboreal mixed forests, overall resulting in a higher grade of heterogeneity in space and time as compared to the boreal forest ecosystems.

Figure 1 gives an overview of the processes that are measured at the SMEAR Estonia station. The movement (flux) of energy and matter within the hemiboreal forest system is characterized by different biological, chemical and physical processes, which link all the parts (atmosphere, ecosystem and soil) of the complex system together. To successfully measure the multitude of environmental and biological characteristics and allow for quantitative simulations and predictions of the pro- cesses, a multidisciplinary and integrated approach is needed (Hari et al., 2015).

\section{Initial steps for the SMEAR Estonia}

Historically, ecophysiological studies along the canopy height gradients started in Järvselja already in 1995 when two canopy towers, $27 \mathrm{~m}$ and $16 \mathrm{~m}$ tall, were established in the mixed forest and studies on understanding within-canopy acclimation of foliage photosynthetic characteristics were initiated. Since then, canopy research has continued in Järvselja (e.g. Niinemets et al., 1998, 1999a,b; Kull \& Tulva, 2002).

The roots of cooperation with Finnish colleagues from the University of Helsinki 
started already in 1970's when Prof. Pertti Hari and the Member of the Estonian Academy of Sciences, Prof. Juhan Ross and Prof. Tiit Nilson started working together on photosynthetically active solar radiation, photosynthesis and forest growth (e.g. Salminen et al., 1983; Hari et al., 1985a,b; Ross et al., 1996). Later, since 2000, a still ongoing collaboration on investigation of atmospheric aerosol particles and air ions between the University of Helsinki and University of Tartu, initiated by Prof. Markku Kulmala and Prof. Hannes Tammet, was established (Aalto et al., 2001; Kulmala \& Tammet, 2007; Kulmala et al., 2016). Starting from 2008, integrated ecosystem-atmosphere measurements were conducted in cooperation of the Estonian University of Life Sciences, the University of Tartu and the Tartu Observatory. These efforts led to the building of the SMEAR Estonia measurement station in its present form and establishment of SMEAR Estonia as a part of the "Estonian Research Infrastructures Roadmap" project Estonian Environmental Observatory (Kadastik \& Tamm, 2010; Leiner \& Tamm, 2015).

The SMEAR Estonia station, located at $58.2714 \mathrm{~N}, 27.2703 \mathrm{E}$ at $36 \mathrm{~m}$ a.s.l., is situated at the Järvselja Experimental Forestry Centre (Figure 2). It is the southernmost SMEAR station in the SMEAR network spanning from the subarctic SMEAR I station in Värriö, Finnish Lapland via Kuopio

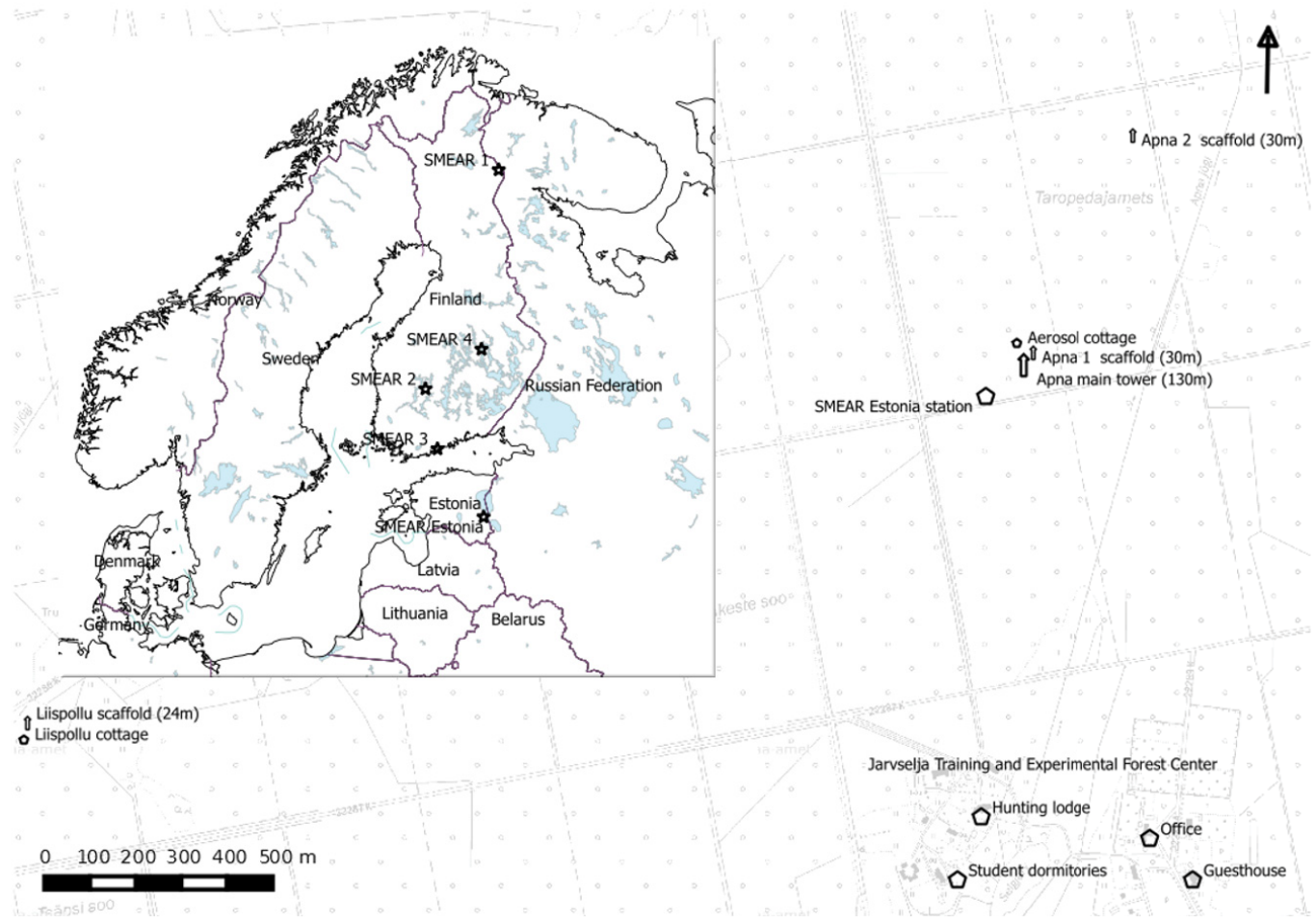

Figure 2. Location and schematic overview of the SMEAR Estonia station. Beside the measurement area there are facilities to host guest researchers at Järvselja Training and Experimental Forestry Centre.

Joonis 2. SMEAR Eesti asukoha ja mõõtejaama objektide paiknemine Järvselja Õppe- ja Katsemetskonnas. Mõõteala kõrval saavad külalisuurijad kasutada metskonna erinevaid majutus- ja tööruume. 
(SMEAR IV), Hyytiälä (SMEAR II) to the urban station in Helsinki (SMEAR III) (see https://www.atm.helsinki.fi/SMEAR/) and further towards Central-Eastern Estonia. This network of stations covers a unique long distance transect over northern Europe where comprehensive and continuous long-term measurements are conducted (Hari et al., 2015).

\section{Site description}

The forests surrounding the SMEAR Estonia station can in general be described as hemiboreal (Ahti et al., 1968). The experimental centre covers 10,408 hectares from which $62.7 \%$ is forested land $(6,526 \mathrm{ha})$ and $30.2 \%$ is wetland $(3,147 \mathrm{ha})$. The local climate is influenced by continental air masses from Siberian plains, Northern Fennoscandia or by maritime influence from the coast of the Baltic Sea and the Lake Peipus. The mean annual temperature is 4-6 ${ }^{\circ} \mathrm{C}$ and mean annual precipitation is $500-750 \mathrm{~mm}$ from which about $40-80 \mathrm{~mm}$ falls as snow. The length of the growing season (with daily air temperature above $5^{\circ} \mathrm{C}$ ) ranges between 170 and 190 days.

Depending on the location and high variability in soil, the forests in the footprint of SMEAR Estonia are very heterogeneous with typical soils being gleyed and gleyic pseudopodzolic soils, often with a raw humus horizon in wetter places. In the area, birch species (Betula pendula Roth and B. pubescens Ehrh.) dominate or co-dominate with coniferous species Scots pine (Pinus sylvestris L.) and Norway spruce (Picea abies (L.) Karst.). Aspen (Populus tremula L.) grey alder (Alnus incana (L.) Moench) and black alder (A. glutinosa (L.) Gaertn.) form mixtures with birch species and conifers or other broadleaves in earlysuccessional forest patches, while in latesuccessional sites, Tilia cordata Mill. becomes increasingly dominant. Apart from the native species, there are scattered small stands of exotic species such as Abies spp., Larix spp. and Pinus spp. planted within historical forest trial experiments by the In- stitute of Forestry and Rural Engineering, Estonian University of Life Sciences.

The station has a $130 \mathrm{~m}$ high atmospheric measurement mast and a main cottage (Apna), which hosts the main power supply and power backup, provides internet access, a storage server for online data, controls for information technology solutions, and the pumping facilities and gas analysers for the large atmospheric mast. The cottage has climate-controlled rooms to ensure proper working conditions for the analysers and other technical systems. The main power system provides $0.38 \mathrm{kV}$ with $3 \times 100 \mathrm{~A}$ at the connection point linking the station to the public network. Electric power lines $0.2 \mathrm{kV}$ with 3 or $5 \times 16$ A are distributed to the mast, the aerosol cottage, two $30 \mathrm{~m}$ high scaffolding towers and the site for container measurement stations. Additional lines of $0.38 \mathrm{kV}, 3 \mathrm{x}$ $16 \mathrm{~A}$ are distributed to the mast, the main cottage and the container measurement station. The site for mobile container measurement systems can host up to 6 standard shipping containers (approx. $12 \times 2.5$ $x 2.6 \mathrm{~m}$ ) on ground level. The network is distributed by optical fibre connections to the mast, the aerosol cottage, and the two scaffolding towers. A $24 \mathrm{~m}$ high scaffolding tower (Liispõllu) is located $3 \mathrm{~km}$ west of the main station. It is further equipped with a shelter cottage and electrical power of $0.2 \mathrm{kV}, 3 \times 6 \mathrm{~A}$ is available. Online access is possible by cellular network connection.

The official opening ceremony of the SMEAR Estonia station in Järvselja took place on August 23, 2015.

\section{Measurements at SMEAR Estonia}

An overview of the instrumentation employed at the SMEAR Estonia station is given in Supplemental Tables S1 to S3. More detailed descriptions of the measurements for each component are presented in the sections below. 


\section{Meteorological characteristics}

A major characteristic measured is the turbulent wind flow in three dimensions (Metek uSonic-3 Class A, Metek GmbH, Germany) at different locations at the station. These data are logged with $10 \mathrm{~Hz}$ and linked to measurements of concentrations or mixing ratios of gases, allowing estimation of net ecosystem exchange by the Eddy covariance methodology. At the station, a large set of auxiliary data is gathered. Temperature measurements with shielded and ventilated PT-100 resistance thermometers (Metek $\mathrm{GmbH}$, Germany) are conducted from ground level to up to $130 \mathrm{~m}$. Relative humidity and atmospheric pressure are gauged at different heights using specialized sensors or combined weather transmitter instruments. Rain gauges (Vaisala OY, Finland) are also deployed at the SMEAR Estonia station. Solar radiation flux is measured at $40 \mathrm{~m}$ height with pyranometers (SPN-1 Sunshine Pyranometer, Delta-T, UK), whereas the fluxes of total and diffuse incoming radiation and reflected radiation from plant cover and ground are separately assessed. Supporting radiation measurements are conducted nearby at the Järvselja Training and Experimental Forestry Center with a Skyspec spectrometer (developed by J. Kuusk, Tartu Observatory and Interspectrum OÜ, Estonia) covering total and diffuse radiation in the spectral range from $300-2,400 \mathrm{~nm}$.

\section{Atmospheric trace gases}

The most important trace gases measured at the SMEAR Estonia station are carbon dioxide $\left(\mathrm{CO}_{2}\right)$, water vapour $\left(\mathrm{H}_{2} \mathrm{O}\right)$ and methane $\left(\mathrm{CH}_{4}\right)$ (G2401, Picarro Inc., USA and LGR GGA, Los Gatos Research Inc., USA) which are called greenhouse gases because of their ability to absorb and emit infrared radiation and by that propagate heat storage and transfer within the atmosphere. Reactive trace gases measured are ozone $\left(\mathrm{O}_{3}\right)$ (Model 49i, Thermo Fisher Scientific Inc., USA), nitrogen oxides $\left(\mathrm{NO}_{x}=\right.$ $\left.\mathrm{NO}+\mathrm{NO}_{2}\right)($ Model 43i-TL, Thermo Fisher
Scientific Inc., USA) and sulphur dioxide $\left(\mathrm{SO}_{2}\right)$ (Model 42i-TLE, Thermo Fisher Scientific Inc., USA), whereas ozone is also graded as a greenhouse gas. All these trace gases are measured continuously with frequencies between $10 \mathrm{~Hz}$ to once per $10 \mathrm{sec}-$ onds at different heights from ground level to up to $110 \mathrm{~m}$ height. The SMEAR station can provide $\mathrm{CO}_{2}$ and $\mathrm{H}_{2} \mathrm{O}$ concentrations at a multitude of heights, five at the atmospheric mast $(30,50,70,90$, and 110 $\mathrm{m}$ ), the scaffolding ecosystem towers (up to $30 \mathrm{~m}$ ) and on the ground level (the soil chamber measurements). During episodic campaigns, plant emitted volatile organic compounds (VOC) with proton transfer reaction mass spectrometry (PTR-QMS and PTR-TOF systems, Ionicon, Innsbruck, Austria) are measured.

\section{Atmospheric particulate matter and air ions}

Beside greenhouse gases, atmospheric aerosol particles are recognized as the most important factor affecting the atmospheric radiation balance and thereby the Earth weather and climate (IPCC, 2014). The impacts associated with aerosols are direct or indirect. In the case of the direct effect the particles absorb or scatter solar radiation (Yu et al., 2006). In the case of indirect impacts the particles act as condensation nuclei for cloud droplet formation (Lohmann \& Feichter, 2005). The aerosol particles can not only affect cloud formation, but also cloud microphysical properties leading to changes in e.g. cloud albedo, precipitation formation and precipitation patterns (Kulmala et al., 2008; Spracklen et al., 2008; Mahowald, 2011; Kerminen et al., 2012; Westervelt et al., 2014). The aerosol effects on climate are more uncertain than warming associated with greenhouse gases (Stocker et al., 2013).

The investigation of aerosol particle formation from atmospheric trace gases via gas-to-particle-conversion, including neutral and ion-induced nucleation, and their subsequent growth towards larger sizes to 
become Aitken particles and even accumulation mode sizes (Mäkelä et al., 1997; Kulmala et al., 2001; Tammet et al., 2013; Luts et al., 2015) is one of the main objectives of aerosol research carried out at the SMEAR Estonia station. These measurements at SMEAR Estonia are based on the knowledge obtained in the development of aerosol instrumentation in the University of Tartu and long term measurements of air ions and aerosol particles at Tahkuse station, Estonia (Hõrrak et al., 1994, 1998, 2000; Hirsikko et al., 2011; Tammet et al., 2014). The station is equipped with various spectrometers for precise measurements of aerosol particle and air ion size distributions.

The basic research instruments have been so far the Electrical Aerosol Spectrometer (EAS, Tammet et al., 2002) and Neutral Cluster and Air Ion Spectrometer (NAIS, Mirme \& Mirme, 2013), which measure the particle size distribution in the size range from $3 \mathrm{~nm}$ to $10 \mu \mathrm{m}$ and from 0.8 to $42 \mathrm{~nm}$, respectively. A nano condensation nucleus counter (A11 nCNC, Airmodus OY, Finland) enables measurements of the smallest nanoparticles in the activation size range of 1-3 nm (Vanhanen et al., 2011)calibrated and tested in atmospheric measurements. The working principle of a PSM is to mix turbulently cooled sample flow with heated clean air flow saturated by the working fluid. This provides a high saturation ratio for the working fluid and activates the seed particles and grows them by condensation of the working fluid. In order to reach high saturation ratios, and thus to activate nano- $\mathrm{CN}$ without homogeneous nucleation, diethylene glycol was chosen as the working fluid. The PSM was able to grow nano$\mathrm{CN}$ to mean diameter of $90 \mathrm{~nm}$, after which an ordinary condensation particle counter was used to count the grown particles (TSI 3010. The aerosol particle and air ion size distributions are all measured continuously and the data are recorded typically as $5 \mathrm{~min}$ averages. To connect the aerosol and ion measurements to the atmospherebiosphere interactions, the FMPS (Fast
Mobility Particle Sizer TSI 3091, TSI Inc., USA), OPS (Optical Particle Sizer TSI 3330, TSI Inc., USA), LAS (Laser Aerosol Spectrometer, TSI 3340, TSI Inc., USA) enable fast measurements with a time resolution of 1 s. The Neutral Air Ion Spectrometer (NAIS, Airel Ltd., Estonia) in connection with a uSonic-3 Class A anemometer is used to develop a method for size resolved particle flux measurements. These instruments enable the measurement in a very wide size range beginning from the smallest cluster ions with sizes about $0.4 \mathrm{~nm}$ up to the size of coarse aerosol particles of 20 $\mu \mathrm{m}$ (including well-known indices PM2.5 and PM10 used for monitoring of health effects of particles). A detailed instrument list is presented in Table S1.

In addition, measurements of key characteristics affecting the ionization rate of air (or production rate small air ions) are planned and appropriate devices - the gamma radiation monitor GammaTRACER XL2-3 (Saphymo GmbH, Germany) and radon $\left({ }^{222} \mathrm{Rn}\right.$,) monitor AlphaGuard (Saphymo GmbH, Germany) are waiting for installation. Radon is the main factor causing the variability of the ionization rate of air is also indicator of atmospheric boundary layer stability (e.g. Chen et al., 2016).

First aerosol particle size distributions and air ion electrical mobility distributions were measured at Liispõllu site at a height $1.8 \mathrm{~m}$ and on the top of $24 \mathrm{~m}$ tower. These measurements were carried out during 2008-2010 as short campaigns followed by continuous measurements starting in June 2012 in Liispõllu and since August 2015 at the new Apna site to find out differences in the aerosol particle size distribution evolution between the atmosphere above and within a relatively closed forest canopy. We further intend to measure the vertical gradient and fluxes of aerosol particles by Eddy-covariance method.

\section{Stand level measurements}

The principal units of stand description for SMEAR Estonia are circular plots with 
variable plot size (radius 15, 20, 25 or 30 $\mathrm{m})$. The plot sizes depend on tree density and stand age and are expected to include at least 100 trees from the main forest canopy. The general setup of the circular stand plot follows the measurement protocol of the Estonian Network of Forest Research Plots (ENFRP) (Kiviste et al., 2015). The plot locations are expected to follow a 50x50 m grid within the footprint areas of the flux towers. Therefore, there can be one or more plots within the same tree stand depending on its size and location. All living and dead trees, snags, coarse woody debris, shrubs and advanced regeneration growth are explicitly recorded. In this analysis, a tree is defined arbitrarily as a singlestemmed woody plant with the diameter at $1.3 \mathrm{~m}$ above the root collar (diameter at breast height, DBH) $>6 \mathrm{~cm}$. Every sample plot is re-measured in five-year intervals.

For all the living trees $\mathrm{DBH}$ is recorded in two perpendicular directions. Tree height and height to tree crown base are measured also for all trees, and the height to the first dead branch is recorded for conifers. The age of different tree species in the given plot is estimated from tree-ring cores taken from trees outside the plots. Tree damages and causes of tree mortality are assessed and recorded for all trees within the sample plot.

The ground vegetation is sampled in the area of $400 \mathrm{~m}^{2}$ inside the plot using the description method developed by Kent and Coker (1993) (see Figure 9).

\section{Tree level measurements}

Scaffolding towers up to $30 \mathrm{~m}$ height were built in the vicinity of the $130 \mathrm{~m}$ tall atmospheric measurement tower and allow direct access to the branches of coniferous and broad-leaved deciduous tree species. These towers host flux measurements (Metek uSonic-3 Class A, Metek GmbH, Germany and LI7200, LiCor Inc., USA) to characterize the productivity of the nearby stand. Further, branch enclosures are installed to measure the direct gas-exchange fluxes from the photosynthesizing tissues. These chamber measurements allow also direct measurement of VOC emissions from the plants to the atmosphere. In the future canopy light extinction profiles will be estimated utilizing these towers. Dendrometers (DC3, Ecomatik, Germany) installed at several trees in the plots are used to assess changes in stem radius related to growth but as well as reaction to environmental parameters.

\section{Soil measurements}

Soil traits are measured using a diverse set of sensors $\left(\mathrm{CO}_{2}\right.$ e.g. Vaisala GMP343, Vaisala OY, Finland) and chamber systems. Since 2015, soil water content is measured (Soil Moisture Probe (PR2) and ThetaProbe Soil Moisture sensor (ML3), both Delta-T, UK) at 5, 10, 20, 30, 40, 60, $100 \mathrm{~cm}$ depth at several points per sample plot to account for heterogeneity and to give representative data for surrounding area. Soil temperature is measured (KM330, Comark Instuments, UK) at 5 and $10 \mathrm{~cm}$ depth. We currently employ both automated ( $2 x$ ACE automated soil $\mathrm{CO}_{2}$ Exchange system, ADC BioScientific Ltd., UK) and manual soil chambers (10x Polymethyl methacrylate and $2 x$ zinc coated tin, (e.g. Pihlatie et al., 2013)) to assess soil $\mathrm{CO}_{2}$ fluxes. While currently manual probing dominates, the share of automated chambers will be increased to 10 systems to allow all season comprehensive measurements. All sensors are positioned such that the heterogeneity of the study area is covered and taken into account. To assess belowground biomass and soil structural characteristics ingrowth nets and coring techniques are applied.

\section{Examples of representative SMEAR Estonia data obtained so far}

\section{Meteorological measurements}

Figure 3 shows selected meteorological data measured at several heights at the atmospheric mast. Over a season starting in 

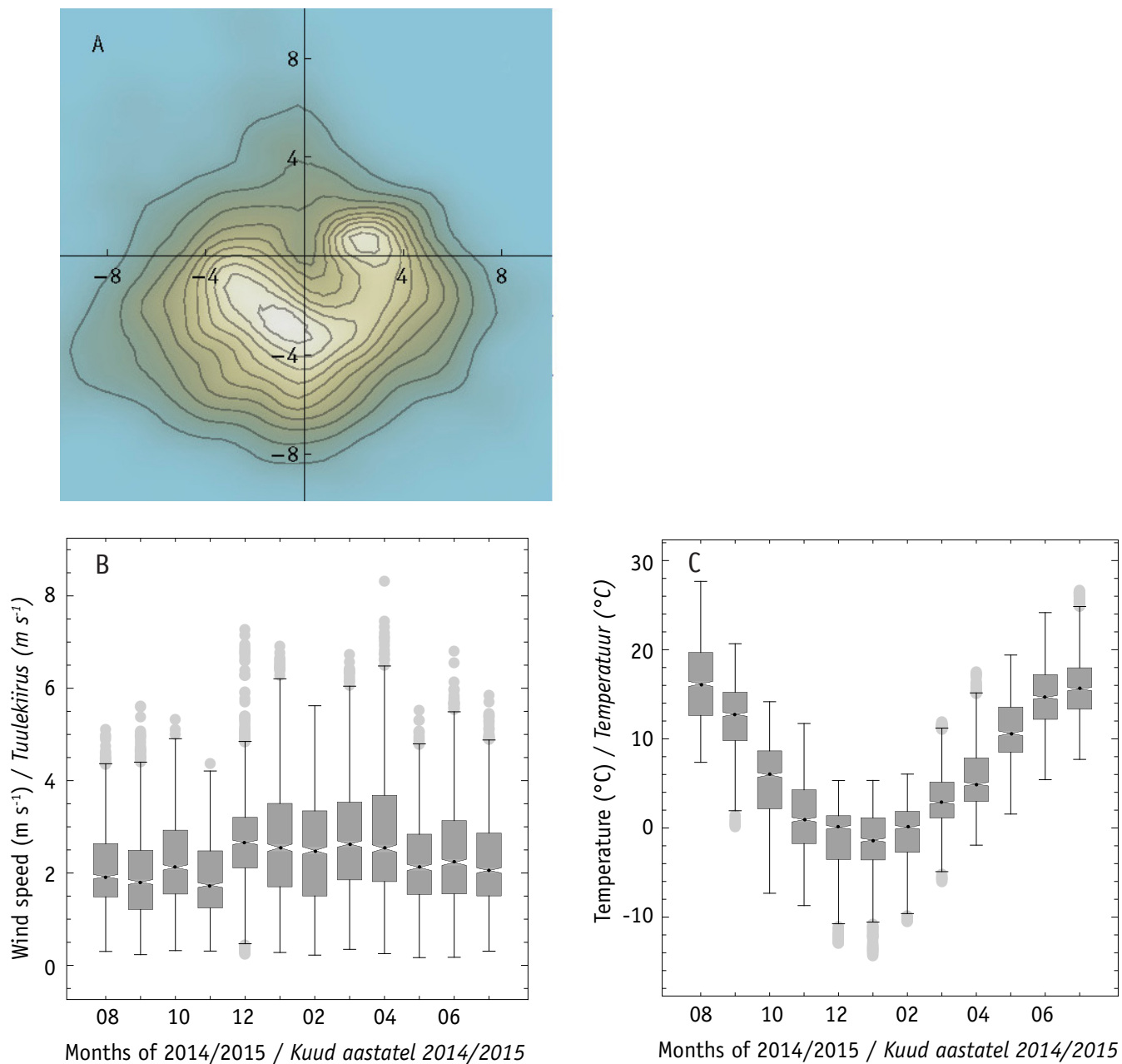

Figure 3. Meteorological data measured at $30 \mathrm{~m}$ height at the $130 \mathrm{~m}$ tall atmospheric mast. Plot (A) shows the spatial distribution of the horizontal wind directions measured from August 2014 to July 2015. The colour gives the density of horizontal wind vectors, where greenish to lighter colours are linked to a higher probability and therefore higher frequency of wind vectors with a given speed and direction. Blue tones denote a low probability of wind vectors. The isolines visualize the slopes of the underlying wind field's probability density function and have been chosen equally in steps of 0 to the maximum probability $(\mathrm{Pm})$ in steps of $0.1 \mathrm{Pm}$. The mast centre is at the zero point and the axes give the wind speed $\left(\mathrm{m} \mathrm{s}^{-1}\right)$. The $y$-axis denotes the North-South direction and $x$-axis the West-East direction. Plot (B) shows the monthly binned median wind speeds at $30 \mathrm{~m}$. Outliers are given as light grey dots and the boxes span between the $25 \%$ and $75 \%$ quantiles. The rightmost plot (C) shows the monthly binned median temperature at $30 \mathrm{~m}$ height.

Joonis 3. Apna 130 meetri kõrguse masti meteoroloogilised andmed mõõdetuna 30 meetri kõrgusel maapinnast. Horisontaalsed tuulesuunad (A) on mõõdetud vahemikus august 2014 kuni juuli 2015. Värvidega on näidatud mõõdetud tuulevektorite tihedus, sealjuures rohelised ja heledamad toonid viitavad tuule suuremale esinemistõenäosusele ja seega ka tuulevektorite kõrgemale esinemissagedusele vastavas suunas ja kiirusel. Sinised toonid osutavad tuulevektorite madalale esinemistõenäosusele. Masti asukoht on arvestatud joonise nullpunktiks, telgedel on esitatud tuulekiirus ( $\left.m \mathrm{~s}^{-1}\right)$ põhjalõuna (y-telg) ning lääne-ida (x-telg) suunas. Joonisel on esitatud vaatlusperioodi kuude keskmised tuulekiirused (B) ja temperatuurid (C). Karbid tähistavad joonistel kvantiili vahemikus $25 \%-75 \%$ ning hallid täpid erindeid. 
August 2014 and ending in July 2015 we present data on the horizontal wind speed, wind direction and temperature measured above the forest canopy on $30 \mathrm{~m}$ height. Over this period the major wind directions on that height are south to southwest and northeast to east (Figure 3A). The highest frequency in horizontal wind speed ranged between 2 to $4 \mathrm{~m} \mathrm{~s}^{-1}$. That finding is also supported by Figure $3 \mathrm{~B}$ where the monthly binned medians of the horizontal wind speed are shown. At this height, the wind speed during summer was rather uniformly around $2 \mathrm{~m} \mathrm{~s}^{-1}$ and the variability is slightly smaller than in autumn, winter and spring. The highest monthly median wind speed was observed in December 2014 and the highest variability was in April 2015. In Figure 3C the seasonal change of the monthly median temperature is shown. Compared to the long term (1981-2010) averaged monthly air temperature measured at the nearest meteorological measurement stations of the Estonian Weather Service (http://www. ilmateenistus.ee/kliima/kliimanormid/ ohutemperatuur/?lang=en) the winter median temperatures are about $4^{\circ} \mathrm{C}$ above the long term average while summer median temperatures remained with 16-17 ${ }^{\circ} \mathrm{C}$ in the range of the long term averages. The station measures these data with a frequency of $10 \mathrm{~Hz}$ and therefore a multitude of averaged data can be generated. The standard averaging period is 30 minutes.

\section{Trace gases}

Trace gas measurements were started in the summer of 2012 at Liispõllu and Apna locations at several heights. Since October 2013, measurements have been carried out continuously. Thus, we can provide a full seasonal and diurnal dynamics of the trace gases measured, including $\mathrm{CO}_{2}$ and $\mathrm{H}_{2} \mathrm{O}$ mixing ratios (Figure 4 for data for August 2014 to July 2015). Median monthly $\mathrm{CO}_{2}$ mixing ratios (Figure $4 \mathrm{~A}$ ) were around 400 ppm with values below 400 ppm during the vegetation period (May to September).
Because of the daily photosynthetic activity, the variability in the mixing ratios was the highest during these months. During winter dormancy period (October to April), the deciduous trees have shed the leaves and the activity of coniferous trees was low. Thus, during these months, the background $\mathrm{CO}_{2}$ mixing ratio was above 400 ppm and the variability was lower than during the growing season. Water vapour mixing ratio (Figure 4B) was strongly linked to the air temperature at the given height (see Figure 3C).

Monthly medians of ozone mixing ratios reveal that during spring, the ambient ozone levels are the highest and during autumn the lowest (Figure 5A). A comparison of the diurnal dynamics (Figure 5B) during spring, summer and autumn shows that in spring and autumn this variability was weak; the daily variation in November was about $5 \mathrm{ppb}$, whereas in April it was about $10 \mathrm{ppb}$. The daily cycle is strong in summertime, when half an hour median ozone mixing ratio can vary by $25 \mathrm{ppb}$ due to the activity of the ecosystem and the atmospheric photochemical cycle (Atkinson et al., 1990; Atkinson, 2000; Hewitt et al., 2011; Pusede \& Cohen, 2012). Another example we show is the ambient median NO mixing ratio (Figure 6A) and its dependency on height. One of the natural sources of NO is the soil emission (Kesik et al., 2005; Pilegaard, 2013) and we found typically higher levels of NO near ground than at $30 \mathrm{~m}$ height indicating a stronger local impact. At the same time $\mathrm{NO}_{2}$ (Figure 6B) remained almost constant at both heights indicating that larger scale processes determine its atmospheric mixing ratio. Generally the variability in $\mathrm{NOx}\left(=\mathrm{NO}+\mathrm{NO}_{2}\right)$ mixing ratios above the forest canopy is influenced by a combination of local natural and anthropogenic emissions due to local sources like combustion of fossil fuels due to heating, especially during winter period, local and distant atmospheric chemistry processes and longer distance transport from neighbouring areas (Noe et al., 2016). 

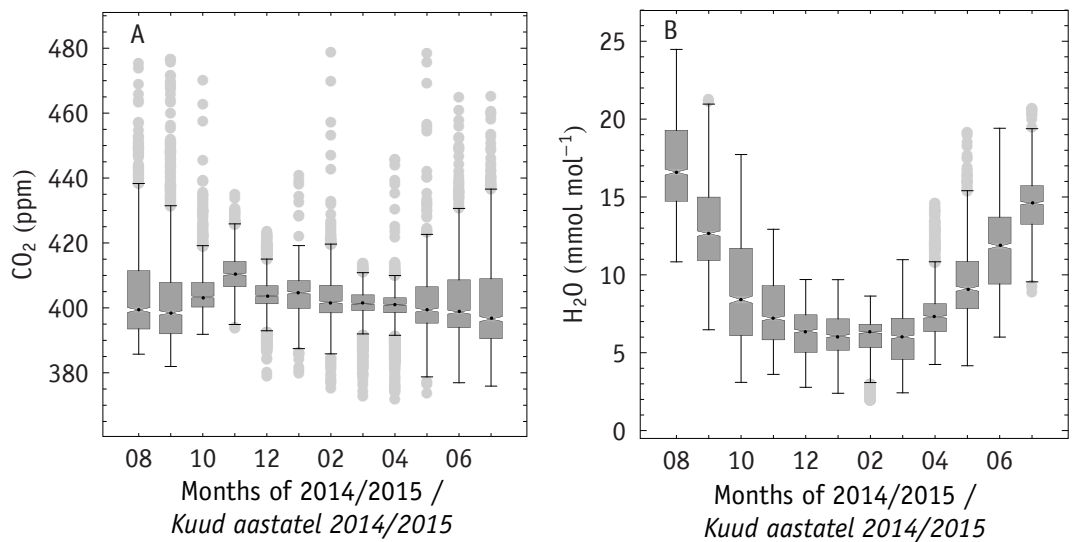

Figure 4. Binned monthly median $\mathrm{CO}_{2}(\mathrm{~A})$ and water vapour (B) mixing ratios are for the period August 2014 to July 2015, measured at $30 \mathrm{~m}$ height. While median $\mathrm{CO}_{2}$ mixing ratios vary around 400 ppm (lower in summer, higher in winter) the photosynthetic activity of the trees lead to higher variability during the growing season. Water vapour follows to large extent the air temperature (Fig. $3 C$ ) and has lowest values during cold months.

Joonis 4. $\mathrm{CO}_{2}(A)$ ja veeauru (B) kontsentratsioonide kuude mediaanid vaatlusperioodil (august 2014 kuni juuli 2015) mõõdetuna Apna mastis 30 meetri kõrguselt. Kui $\mathrm{CO}_{2}$ kontsentratsioon õhus varieerub 400 ppm lähedal (suvel on madalam ja talvel kõrgem), siis puude fotosünteetiline aktiivsus suurendab kasvuperioodi jooksul kuusisest varieeruvust. Veeauru kontsentratsioon õhus järgib valdavalt õhutemperatuuri muutumisi (vt joonis 3C) ning on madalaim külmadel talvekuudel.
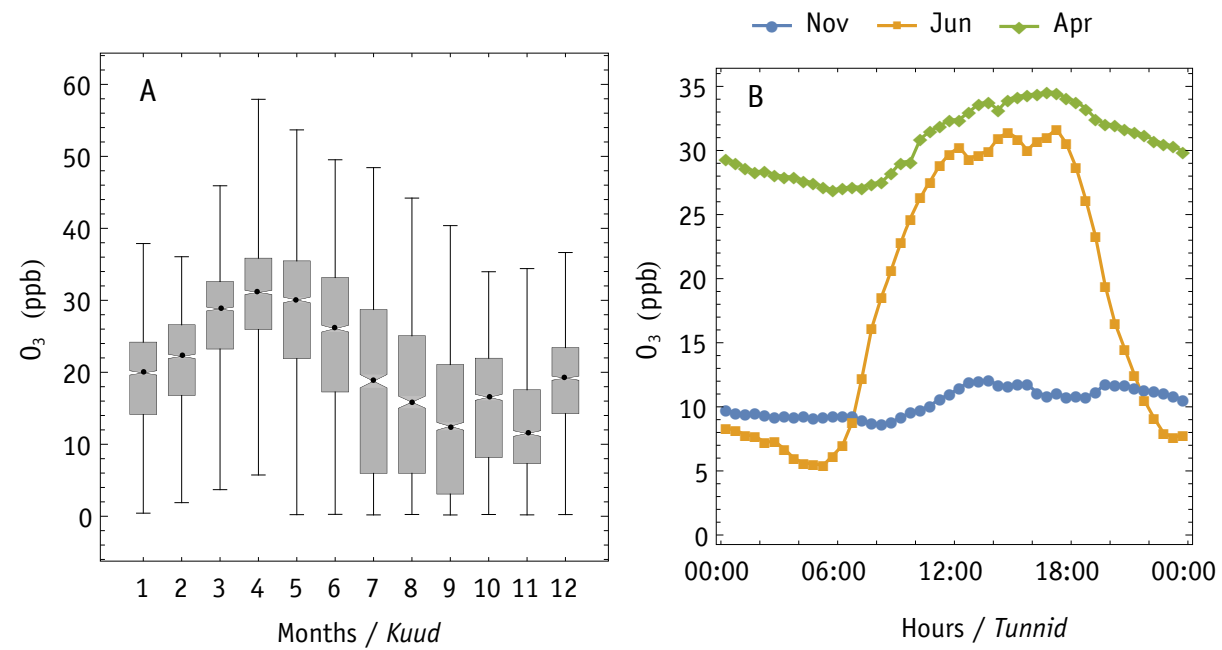

Figure 5. Example of the seasonal dynamic of monthly median ozone mixing ratios measured at $30 \mathrm{~m}$ height above the canopy (A). Besides the seasonal dynamic, ozone changes according to the energy input by sunlight on a diurnal scale (B). Comparing the diurnal dynamics for different seasons the impact of light availability, temperature and trace gases participating the photochemical ozone formation process are visible.

Joonis 5. Osooni kontsentratsioonide kuude mediaanide dünaamika aasta lõikes (A) ja päevaste kontsentratsioonide dünaamika mõõdetuna metsa kohal 30 meetri kõrguselt. Osooni kontsentratsioon ööpäevasel skaalal muutub olenevalt päikesekiirgusest (B). Ö̈̈päevased osoonimuutused on tingitud päikesekiirguse, temperatuuri ning teiste kasvuhoonegaaside mõjust osooni fotokeemilisele tekkeprotsessile. Ö̈̈päevaste käikude võrdlemine erinevate aastate erinevatel aastaaegadel loob võimalused nende vastastikmõjude kirjeldamiseks. 

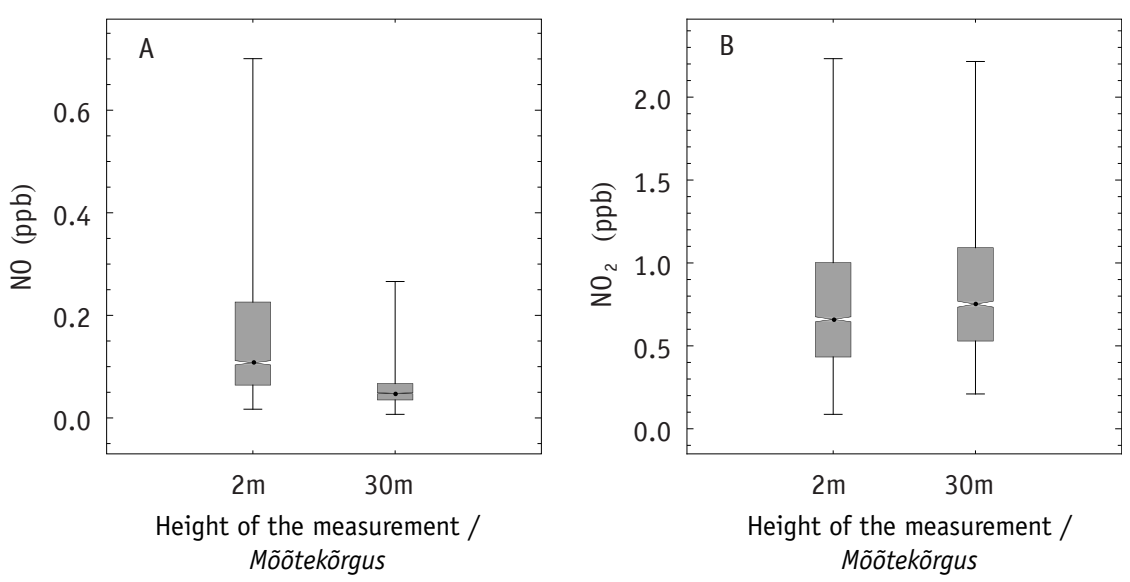

Figure 6. Example of differences in $\mathrm{NO}$ and $\mathrm{NO}_{2}$ mixing ratios as dependent on the height of the measurement $(2 \mathrm{~m} v$ v. $30 \mathrm{~m}$ ). NO concentrations are more influenced by the local situation (within-canopy position, turbulence conditions, radiation intensity, concentrations of reactive trace gases, emissions from soil processes). $\mathrm{NO}_{2^{\prime}}$ on the contrary, seems to be influenced by atmospheric largerscale processes.

Joonis 6. $\mathrm{NO}(A)$ ja $\mathrm{NO}_{2}(B)$ konsentratsioonide sõltumine ainevoogude mõõtekõrgusest (2 meetrit võrrelduna 30 meetrit maapinnast). NO kontsentratsioonid sõltuvad palju rohkem kohalikust olukorrast (võrasisene asukoht, õhuliikuvus, päikesekiirgus, teiste kasvuhoonegaaside konsentratsioonid ja emissioon mullahingamisest). Vastupidi NO kontsentratsioonidele sõltub $\mathrm{NO}_{2}$ kohalikest mõjuritest palju vähem ning tugevamalt sõltub atmosfääri suurematest ainevoogudest.

For volatile organic compounds (VOC) we characterized their spatial and seasonal variability in ambient air (Noe et al., 2012). Especially for ambient monoterpene concentrations that play a role in the formation and growth of aerosol particles (Spracklen et al., 2008; Metzger et al., 2010) the structure of the dense hemiboreal mixed forest during the vegetation period led to high concentrations in the lower forest canopy. Isoprene, monoterpene and sesquiterpene emissions from the vegetation surface (leaves and needles) where measured using branch enclosure cuvettes (Noe et al., 2011; Bourtsoukidis et al., 2014).

\section{Fluxes}

There are two major types of fluxes measured at the SMEAR Estonia station: energy and matter. Energy fluxes are assessed by measuring the total and diffuse direct and reflected solar radiation, the photosynthetically active radiation and the latent heat in the atmosphere. Fluxes of matter in the form of water vapour, biomass and gases are measured at several heights within the atmosphere-biosphere-soil continuum. The measurement techniques for particulate matter (aerosol particles) fluxes are under development (see section: Atmospheric particulate matter and air ions) and currently only vertical gradients of particle concentration can be estimated.

The SMEAR Estonia station has continuous flux measurements using the Eddy covariance methodology since April 2014, which is the longest continuous data set on $\mathrm{CO}_{2}$ and $\mathrm{H}_{2} \mathrm{O}$ fluxes available in Estonia (Figure 7). Prior Eddy flux measurements root back to 2008 (Noe et al., 2011) but have been episodic. Carried out on $30 \mathrm{~m}$ and 70 $\mathrm{m}$ heights, the footprint areas covered by the flux measurements at the $130 \mathrm{~m}$ mast reach up to $1.5 \mathrm{~km}^{2}$ for the $30 \mathrm{~m}$ system and $4.5 \mathrm{~km}^{2}$ for the $70 \mathrm{~m}$ system. Within these fetch areas, the protected primeval forest quarter and different forest site types under different forest management regimes are located. This heterogeneity provides the possibility to study changes in carbon 


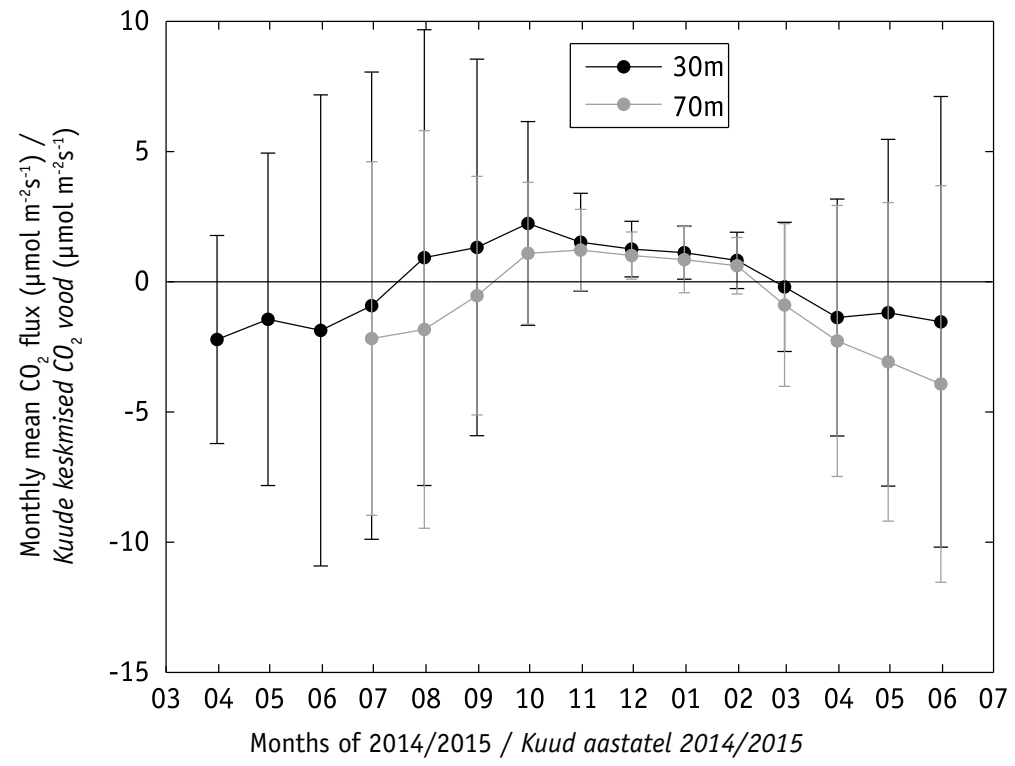

Figure 7. Monthly mean $\mathrm{CO}_{2}$ fluxes obtained from the longest available continuous flux dataset in SMEAR Estonia. Negative fluxes denote the carbon uptake by the forest within the fetch area and positive fluxes denote the ecosystem respiration flux. The error bars are standard deviations of the monthly mean $\mathrm{CO}_{2}$ fluxes to visualize the spread of the data. Overall, it is visible that the higher $(70 \mathrm{~m})$ measurements, corresponding to a distance from the mast of up to $4.5 \mathrm{~km}$, are less influenced by local drivers than the lower $(30 \mathrm{~m})$ measurements corresponding to up to $1.5 \mathrm{~km}$. The larger fetch and less impact of forest floor respiration fluxes and canopy shape lead to a "smoother" flux result.

Joonis 7. Kuude keskmised $\mathrm{CO}_{2}$ vood praegu pikimast pidevast andmeseeriast SMEAR Eesti mõõtejaamas. Negatiivsed vooväärtused on iseloomulikud metsaökosüsteemi süsiniku sidumisele ning positiivne voog on iseloomulik ökosüsteemi aktiivse hingamise voogudele. Usaldusnivooga on esitatud kuude keskmiste $\mathrm{CO}_{2}$ voogude standardhälved. Jooniselt on näha, et kõrgemalt $(70 \mathrm{~m})$ tehtud mõõtmised vastavad arvestuslikule neeluala ulatusele kuni $4,5 \mathrm{~km}$, neid ei mõjuta kohalikud mõjutused niivõrd kui madalamalt $(30 \mathrm{~m})$ tehtud mõõtmised, mis vastavad neeluala ulatusele kuni 1,5 km. Mida suurem on neeluala ulatus ning väiksem mulla ja alustaimestiku hingamise voo mõju, seda ühtlasem on mõõdetud voog.

exchange between the ecosystem and the atmosphere with different forest growth and management regimes and climatic impact on forest resources.

\section{Aerosols and air ions}

Measurements of air ion and aerosol particles size distributions during last three years (2013-2015) provided a valuable database for studies of new particle formation and growth properties of secondary organic aerosol particles (SOA) in the atmosphere. These measurements (Figures
8 and S2) showed that new particle formation (NPF) at Järvselja was quite frequent in spring (mainly in March-April, Figure S1), when the NPF-events were recorded almost every day. This database enables statistical classification of the NPF-events in accordance with characteristic shapes of the aerosol and air ion size distribution evolution (Hirsikko et al., 2007, 2011; Manninen et al., 2010; Kulmala et al., 2013). The most pronounced NPF-event, with a typical diurnal behaviour of appearance of newly formed particles followed by their 


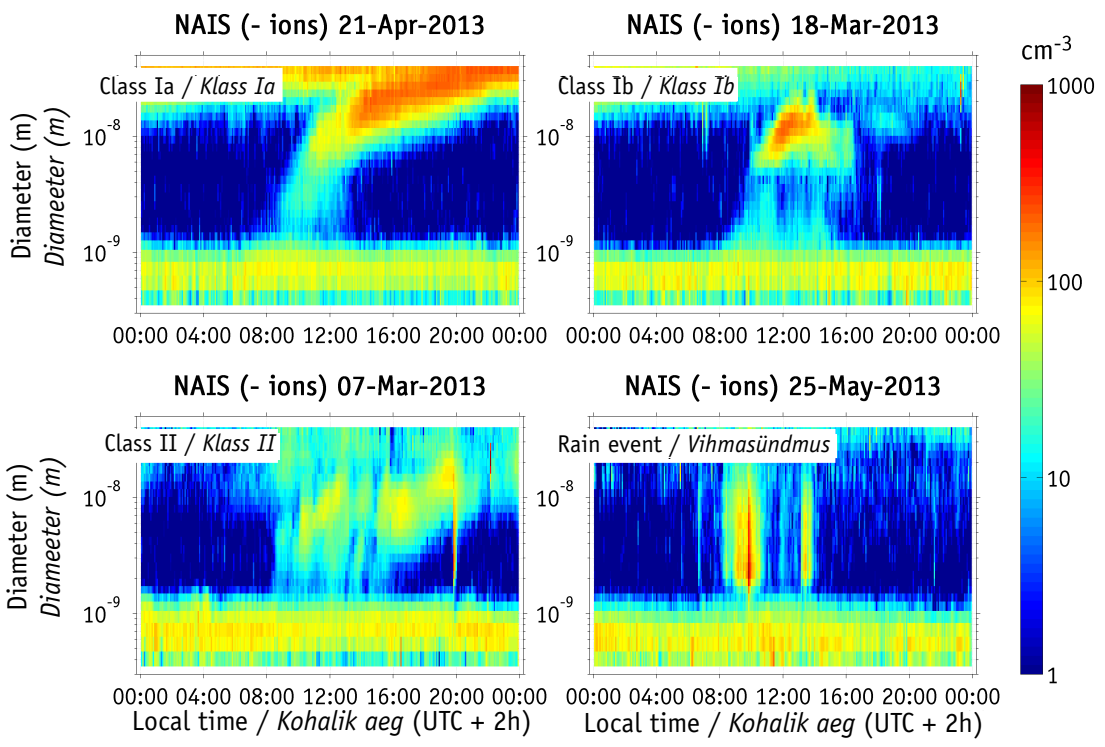

Figure 8. Examples of the classification of new particle formation events obtained from the data recorded in 2014 using classification scheme developed by Hirsikko et al. (2007) and further developed by Manninen et al. (2010).

Joonis 8. Uute aineosakeste tekke klassifitseerimise näited ööpäevaste mõõtekäikude mõõtmisandmetel aastast 2014 Hirsikko et al. (2007) ning Manninen et al. (2010) järgi.

growth to larger sizes that describes a large scale regional event, typically occurring after an inflow of considerably clean Arctic air masses with low concentration of preexisting aerosol particles. This is consistent with the characteristic new particle formation events observed at SMEAR II in Hyytiälä (e.g. Kulmala et al., 2001, 2007, 2013). In these environments, sulphuric acid and possibly stabilizing bases together with extremely low volatile organic vapours are responsible for the formation and growth of the aerosol particles (Kulmala et al., 1998, 2013; Petäjä et al., 2009; Ehn et al., 2014; Riccobono et al., 2014). One specificity of our data is that it includes also cluster ion data and therefore, it enables to study the new particle formation by ion-induced nucleation (Laakso et al., 2004; Gagné et al., 2010). The measurements using the NAIS instrument on top of the $24 \mathrm{~m}$ high tower at Liispõllu showed quite regularly gaps in cluster ion concentrations during nucleation events above the forest canopy. However, these events need future investigations and experimental proof to make any final conclusions.

So far, data from SMEAR Estonia are partly analyzed and compared with other stations and measurement sites in Estonia (Tahkuse, Tartu and Tõravere) and Finland (SMEAR II station). The data from SMEAR Estonia has been used for a comparative analysis of the aerosol nucleation burst events in widely spaced stations in Järveslja, Estonia and in Hyytiälä and Värriö, Finland during an intensive course held in Autumn 2014 in Järvselja (Kulmala et al., 2014a). Some results of the investigations carried out in SMEAR Estonia have been published in conference proceedings, e.g. by Laan et al. (2014) and introduced during recent Finnish-Estonian air ion and aerosol workshops in 2013-2015 (Kulmala et al., 2016). 


\section{Forest stand}

Detailed information about the forest ecosystem at the SMEAR Estonia site is based on the permanent sample plots (Figure 9). There are two different types of plots depending on when they were established. Within the fetch area of the atmospheric measurement mast, there are a few old permanent experimental plots established long before the SMEAR station became functional. There are also forest monitoring plots established with the purpose to cover the footprint area of the station. Old long-term monitoring plots are located in close vicinity of the Apna site. These include old forest growth and yield monitoring plots (in compartments JS222 and JS224, Figure 9) established already in 1925 (Siim \& Kangur, 2013) as well as juvenile stand height dynamics monitoring plots in Apna site established in 2005 (Kängsepp et al., 2014).

The establishment of forest monitoring plots specifically for SMEAR Estonia started in 2008 at the Liispõllu site and continued in 2012 at the newly established Apna site. Liispõllu plots have been re-measured once in 2015 for growth monitoring. For Apna a plot grid was established to ensure consistent point descriptions within the footprint area.

\section{Soil}

Soil temperature and moisture are the important drivers that control many ecosystem processes (Davidson et al., 1998; Curiel Yuste et al., 2007). Being the biggest source of carbon emitted back to the atmosphere, the soil $\mathrm{CO}_{2}$ fluxes (Figure 10A) are needed to assess the ecosystems carbon budget in combination with the Eddy covariance fluxes. Soil water content and soil temperature are the major driving forces of the soil respiratory activity (Figures 10B and 10C). While some soil variables had been available since 2009, these data correspond to shorter campaign measurements and did not cover a full vegetation cycle. Since 2015, the situation has changed and the soil characteristics have been measured on a regular basis through the year.
A

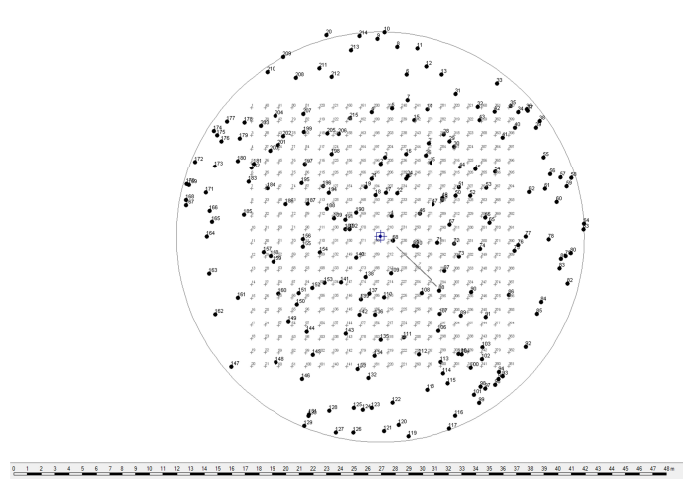

B

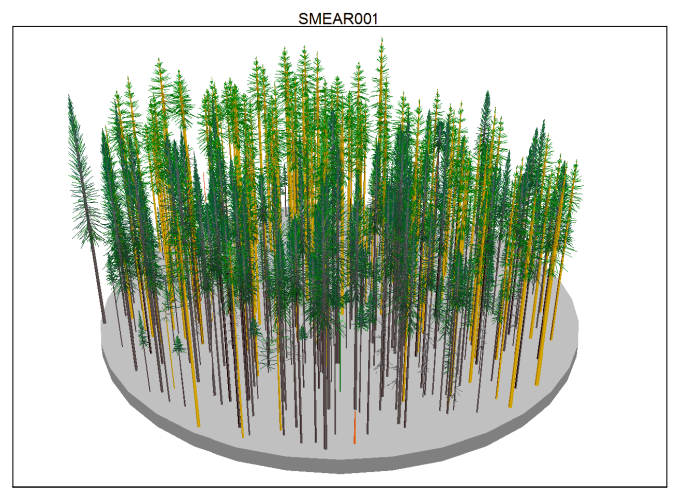

Figure 9. Example of a permanent sample plot in Liispõllu (A) and a three dimensional view (SVS software) of a plot in Apna (B). All measurements on the SMEAR Estonia footprint area follow a systematic grid, where the basic measurement unit is circular plot. Both stand, understory and field flora $(A)$ and tree storey (B) measurements are carried out spatially explicitly.

Joonis 9. Metsaökosüsteemi püsikatseala näide Lïspõllu (A) ja kolmemõõtmeline vaade (SVS tarkvara) Apna (B) neelualalt. SMEAR Eesti mastide neelualadel on põhilised mõõteobjektid ringikujulised püsiproovitükid, mis järgivad süstemaatilist võrkpaigutust. Puistu alustaimestiku mõõtekohad (A) ja üksikpuud (B) kaardistatakse ruumiliselt. 

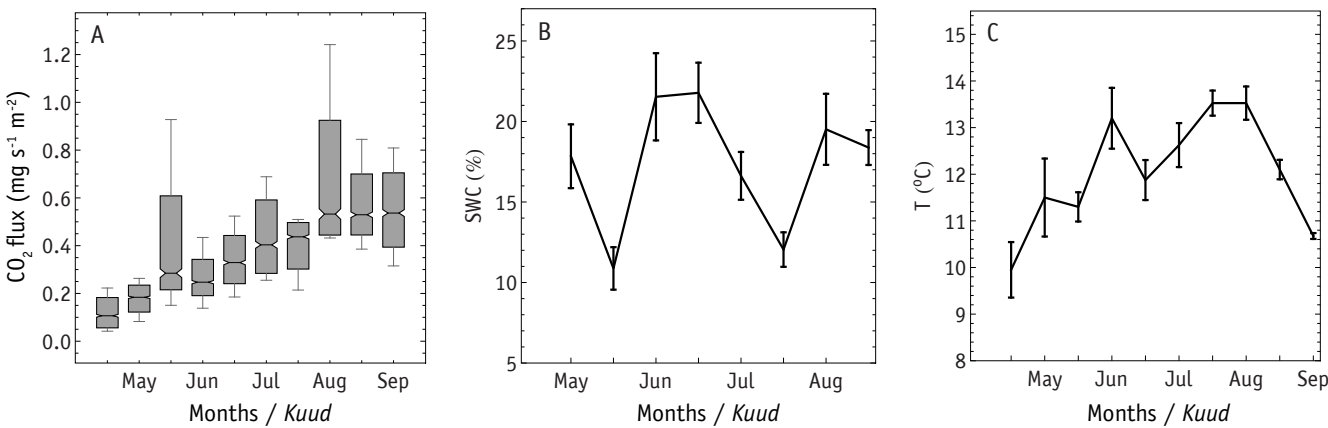

Figure 10. Representative data on soil $\mathrm{CO}_{2}$ flux (A), water content $(\mathrm{B})$ and temperature $(\mathrm{C})$ measured during the vegetation period in 2015 at the SMEAR Estonia station. Soil $\mathrm{CO}_{2}$ flux was measured with the manual chambers, and soil water content and soil temperature were measured at the soil depth of $5 \mathrm{~cm}$.

Joonis 10. Mulla $\mathrm{CO}_{2}$ voogude (A), niiskusesisalduse (B) ja temperatuuri (C) mõõtmistulemused 2015. mõõteaasta mõ̃otmistelt SMEAR Eesti mõõtejaamas. Mulla $\mathrm{CO}_{2}$ voogude mõõtmised on tehtud manuaalkambritega ning mulla niiskusesisaldus ja temperatuur on mõõdetud $5 \mathrm{~cm}$ sügavuselt.

\section{Summary and Future perspectives}

Long-term, comprehensive and continuous integrated soil-plant-atmosphere measurements are of key importance for understanding the dynamics of natural ecosystems and for gaining an insight into the feedback mechanisms between the ecosystems and the environment (Kulmala et al., 2004, 2014b; Paasonen et al., 2013). Thus, the research conducted at SMEAR Estonia provides an important contribution to these research activities, importantly enlarging the scope of SMEAR stations. Furthermore, there are increasing efforts to integrate the long-term measurement sites into a worldwide consortium with standardized measurement protocols and data quality controls, e.g. Integrated Carbon Observation System (ICOS) and ACTRIS (Aerosols, Clouds, and Trace gases Research InfraStructure network) and AnaEE (Analysis and Experimentation on Ecosystems) networks. SMEAR Estonia covers an important part of Earth biomes, hemiboreal forest, and therefore significantly enlarges the coverage of worldwide networks (e.g. FluxNet).

The infrastructure of SMEAR Estonia offers good possibilities to study the forest ecosystem - atmosphere relation, including ecophysiological processes, exchange of atmospheric trace gases and aerosol formation, atmospheric micrometeorology and dynamics, as well as the cross-border propagation of atmospheric pollution. Due to its location far away from bigger cities and industrial regions, the station provides data for Estonian environmental monitoring network (http:/ / airviro.klab.ee/seire/ airviro/en) about regional pollution background.

The SMEAR Estonia station gives opportunity to study diverse forestry management activities and forest type specific differences, e.g. between broadleaf dominated stands and coniferous stands. Already the efforts of building the station led to increased possibilities for national and international cooperation. Smear Estonia participates in the ERA-Planet (http:// www.iia.cnr.it/eraplanet/) network and the Pan Eurasian Experiment (PEEX, https://www.atm.helsinki.fi/peex/index. php). The SMEAR Estonia through its partner, the Institute of Physics, University of Tartu, is also participating in the ACTRIS network as associated partner. 
Although the measurement station is still relatively young compared with several other stations like SMEAR I-IV Finland (https://www.atm.helsinki.fi/SMEAR/), the results obtained so far have already resulted in several new findings like the influence of the dense canopy on trace gas mixing ratios (Noe et al., 2016) and fluxes (Noe et al., 2011) or the ambient concentration of VOC (Noe et al., 2012) that significantly contribute to process-based knowledge of ecosystem and atmosphere functioning.

Further development of the station will increase the set of measurements, improve the quality of observations, and ensure the use of the data produced in research and policymaking. Increasing the level of automation allows for long-term comprehensive measurements and increases the impact of Estonian science on international level and thereby providing possibilities to contribute to world-class research activities.

Acknowledgements. The authors received financial supported by the Estonian Ministry of Science and Education (institutional grants IUT-8-3 and IUT-20-52 and IUT-2011), the European Commission through European Regional Fund (the "Centre of Excellence in Environmental Adaptation", the "Environmental Conservation and Environmental Technology R\&D Programme" project BioAtmos (3.2.0802.110043), the "Internationalization of Science Programme" project INSMEARIN (10.16/13/1028), the "Estonian Research Infrastructures Roadmap" project Estonian Environmental Observatory (3.2.0304.110395)), and the European Research Council (advanced grant 322603, SIP-VOL+).

\section{References}

Aalto, P., Hämeri, K., Becker, E., Weber, R., Salm, J., Mäkelä, J.M., Hoell, C., O'dowd, C.D., Hansson, H.-C., Väkevä, M., Koponen, I.K., Buzorius, G., Kulmala, M. 2001. Physical characterization of aerosol particles during nucleation events. - Tellus $B, 53,344-358$.
Ahti, T., Hämet-Ahti, L., Jalas, J. 1968. Vegetation zones and their sections in northwestern Europe. - Annales Botanici Fennici, 5, 169-211.

Atkinson, R. 2000. Atmospheric chemistry of VOCs and NOx. - Atmospheric Environment, 34, 20632101.

Atkinson, R., Aschmann, S.M., Arey, J. 1990. Rate constants for the gas-phase reactions of $\mathrm{OH}$ and $\mathrm{NO}_{3}$ radicals and $\mathrm{O}_{3}$ with sabinene and camphene at $296 \pm 2$ K. - Atmospheric Environment. Part A. General Topics, 24, 2647-2654.

Bourtsoukidis, E., Bonn, B., Noe, S.M. 2014. On-line field measurements of BVOC emissions from Norway spruce (Picea abies) at the hemiboreal SMEAR-Estonia site under autumn conditions. Boreal Environment Research, 19, 1-15.

Chen, X., Paatero, J., Kerminen, V.-M., Riuttanen, L., Hatakka, J., Hiltunen, V., Paasonen, P., Hirsikko, A., Franchin, A., Manninen, H.E., Petäjä, T., Viisanen, Y., Kulmala, M. 2016. Responses of the atmospheric concentration of radon-222 to the vertical mixing and spatial transportation. - Boreal Environment Research, 21, in press.

Curiel Yuste, J., Baldocchi, D.D., Gershenson, A., Goldstein, A., Misson, L., Wong, S. 2007. Microbial soil respiration and its dependency on carbon inputs, soil temperature and moisture. - Global Change Biology, 13, 2018-2035.

Davidson, E.A., Belk, E., Boone, R.D. 1998. Soil water content and temperature as independent or confounded factors controlling soil respiration in a temperate mixed hardwood forest. - Global Change Biology, 4, 217-227.

Ehn, M., Thornton, J.A., Kleist, E., Sipila, M., Junninen, H., Pullinen, I., Springer, M., Rubach, F., Tillmann, R., Lee, B., Lopez-Hilfiker, F., Andres, S., Acir, I.-H., Rissanen, M., Jokinen, T., Schobesberger, S., Kangasluoma, J., Kontkanen, J., Nieminen, T., Kurten, T., Nielsen, L.B., Jorgensen, S., Kjaergaard, H.G., Canagaratna, M., Maso, M.D., Berndt, T., Petaja, T., Wahner, A., Kerminen, V.M., Kulmala, M., Worsnop, D.R., Wildt, J., Mentel, T.F. 2014. A large source of low-volatility secondary organic aerosol. - Nature, 506, 476-479.

Gagné, S., Nieminen, T., Kurtén, T., Manninen, H.E., Petäjä, T., Laakso, L., Kerminen, V.-M., Boy, M., Kulmala, M. 2010. Factors influencing the contribution of ion-induced nucleation in a boreal forest, Finland. - Atmospheric Chemistry and Physics, 10, 3743-3757.

Hari, P., Andreae, M.O., Kabat, P., Kulmala, M. 2009. A comprehensive network of measuring stations to monitor climate change. - Boreal Environment Research, 14, 442-446.

Hari, P., Kaipiainen, L., Korpilahti, E., Mäkelä, A., Nilson, T., Oker-Blom, P., Ross, J., Salminen, R. 1985a. Structure, radiation and photosynthetic production in coniferous stands. Helsingin Yliopiston Metsänhoitotieteen Laitoksen Tiedonantoja, University of Helsinki, Helsinki, 233 pp. 
Hari, P., Kulmala, M. 2005. Station for Measuring Ecosystem-Atmosphere Relations (SMEAR II). - Boreal Environment Research, 10, 315-322.

Hari, P., Nilson, T., Salminen, R., Kaipiainen, L., Korpilahti, E., Ross, J. 1985b. Nonlinear dependence of photosynthetic rate on irradiance and its consequences for estimates of the amount of saccharides formed. - Photosynthetica, 18, 28-33.

Hari, P., Petäjä, T., Bäck, J., Kerminen, V.-M., Lappalainen, H.K., Vihma, T., Laurila, T., Viisanen, Y., Vesala, T., Kulmala, M. 2015. Conceptual design of a measurement network of the global change. Atmospheric Chemistry and Physics Discussions, 15, 21063-21093.

Hewitt, C.N., Ashworth, K., Boynard, A., Guenther, A., Langford, B., MacKenzie, A.R., Misztal, P.K., Nemitz, E., Owen, S.M., Possell, M., Pugh, T.A.M., Ryan, A.C., Wild, O. 2011. Ground-level ozone influenced by circadian control of isoprene emissions. - Nature Geoscience, 4, 671-674.

Hirsikko, A., Bergman, T., Laakso, L., Dal Maso, M., Riipinen, I., Hõrrak, U., Kulmala, M. 2007. Identification and classification of the formation of intermediate ions measured in boreal forest. Atmospheric Chemistry and Physics, 7, 201-210.

Hirsikko, A., Nieminen, T., Gagné, S., Lehtipalo, K., Manninen, H.E., Ehn, M., Hõrrak, U., Kerminen, V.-M., Laakso, L., McMurry, P.H., Mirme, A., Mirme, S., Petäjä, T., Tammet, H., Vakkari, V., Vana, M., Kulmala, M. 2011. Atmospheric ions and nucleation: a review of observations. - Atmospheric Chemistry and Physics, 11, 767-798.

Hõrrak, U., Iher, H., Luts, A., Salm, J., Tammet, H. 1994. Mobility spectrum of air ions at Tahkuse Observatory. - Journal of Geophysical Research, 99, 10697.

Hõrrak, U., Salm, J., Tammet, H. 1998. Bursts of intermediate ions in atmospheric air. - Journal of Geophysical Research, 103, 13909.

Horrak, U., Salm, J., Tammet, H. 2000. Statistical characterization of air ion mobility spectra at Tahkuse Observatory: Classification of air ions. - Journal of Geophysical Research, 105, 9291.

IPCC. 2014. Climate Change 2013 - The Physical Science Basis. - Intergovernmental Panel on Climate Change (ed.). Cambridge University Press, Cambridge.

Kadastik, E., Tamm, P. 2010. Estonian research infrastructures roadmap 2010. (Eesti teaduse infrastruktuuride teekaart 2010). Haridus- ja Teadusministeerium, Tartu. (In Estonian).

Kent, M., Cocker, P. 1993. Vegetation Description and Data Analysis: A Practical Approach, 2nd Editio. John Wiley \& Sons, New York.

Kerminen, V.-M., Paramonov, M., Anttila, T., Riipinen, I., Fountoukis, C., Korhonen, H., Asmi, E., Laakso, L., Lihavainen, H., Swietlicki, E., Svenningsson, B., Asmi, A., Pandis, S.N., Kulmala, M., Petäjä, T. 2012. Cloud condensation nuclei production associated with atmospheric nucleation: a synthesis based on existing literature and new results. - Atmospheric Chemistry and Physics, 12, 12037-12059.

Kesik, M., Ambus, P., Baritz, R., Bruggemann, N., Butterbach-Bahl, K., Damm, M., Duyser, J., Horvath, L., Kiese, R., Kitzler, B., Leip, A., Li, C., Pihlatie, M., Pilegaard, K., Seufert, S., Simpson, D., Skiba, U., Smiatek, G., Vesala, T., ZechmeisterBoltenstern, S. 2005. Inventories of N2O and NO emissions from European forest soils. - Biogeosciences, 2, 353-375.

Kiviste, A., Hordo, M., Kangur, A., Kardakov, A., Laarmann, D., Lilleleht, A., Metslaid, S., Sims, A., Korjus, H. 2015. Monitoring and modeling of forest ecosystems: the Estonian Network of Forest Research Plots. - Forestry Studies / Metsanduslikud Uurimused, 62, 26-28.

Kratz, T.K., Deegan, L.A., Harmon, M.E., Lauenroth, W.K. 2003. Ecological Variability in Space and Time: Insights Gained from the US LTER Program. - BioScience, 53, 57.

Kull, O., Tulva, I. 2002. Shoot structure and growth along a vertical profile within a Populus-Tilia canopy. - Tree Physiology, 22, 1167-1175.

Kulmala, M., Bäck, J., Petäjä, T., Krüger, O., Hõrrak, U., Noe, S.M. 2014a. Autumn 2014 School - Physics and Chemistry of Air Pollution and Their Effects. [WWW document]. - URL http://smear. emu.ee/smear.php?page=events [Accessed 1 November 2015].

Kulmala, M., Hõrrak, U., Manninen, H.E., Mirme, S., Lehtipalo, K., Junninen, H., Vehkamäki, H., Kerminen, V.-M., Noe, S.M., Tammet, H. 2016. The Legacy of Finnish-Estonian air ion and aerosol workshop. - Boreal Environment Research, 21, in press.

Kulmala, M., Hämeri, K., Aalto, P.P., Mäkelä, J.M., Pirjola, L., Nilsson, E.D., Buzorius, G., Rannik, Ü., Maso, M.D., Seidl, W., Hoffman, T., Janson, R., Hansson, H.-C., Viisanen, Y., Laaksonen, A., $\mathrm{O}^{\prime}$ dowd, C.D. 2001. Overview of the international project on biogenic aerosol formation in the boreal forest (BIOFOR). - Tellus B, 53.

Kulmala, M., Kerminen, V.-M., Laaksonen, A., Riipinen, I., Sipilä, M., Ruuskanen, T.M., Sogacheva, L., Hari, P., Bäck, J., Lehtinen, K.E.J., Viisanen, Y., Bilde, M., Svenningsson, B., Lazaridis, M., Tørseth, K., Tunved, P., Nilsson, E.D., Pryor, S., Sørensen, L.-L., Hõrrak, U., Winkler, P.M., Swietlicki, E., Riekkola, M.-L., Krejci, R., Hoyle, C., Hov, Ø., Myhre, G., Hansson, H.-C. 2008. Overview of the biosphere-aerosol-cloud-climate interactions (BACCI) studies. - Tellus B, 60, 300-317.

Kulmala, M., Kontkanen, J., Junninen, H., Lehtipalo, K., Manninen, H.E., Nieminen, T., Petäjä, T., Sipilä, M., Schobesberger, S., Rantala, P., Franchin, A., Jokinen, T., Järvinen, E., Äijälä, M., Kangasluoma, J., Hakala, J., Aalto, P.P., Paasonen, P., Mikkilä, J., Vanhanen, J., Aalto, J., Hakola, H., Makkonen, U., Ruuskanen, T., Mauldin, R.L., Duplissy, J., Vehkamäki, H., Bäck, J., Kortelainen, A., Riipinen, I., Kurtén, T., Johnston, M. V, Smith, J.N., Ehn, M., 
Mentel, T.F., Lehtinen, K.E.J., Laaksonen, A., Kerminen, V.-M., Worsnop, D.R. 2013. Direct observations of atmospheric aerosol nucleation. - Science, 339, 943-946.

Kulmala, M., Lappalainen, H.K., Petäjä, T., Kurten, T., Kerminen, V.-M., Viisanen, Y., Hari, P., Sorvari, S., Bäck, J., Bondur, V., Kasimov, N., Kotlyakov, V., Matvienko, G., Baklanov, A., Guo, H.D., Ding, A., Hansson, H.-C., Zilitinkevich, S. 2015. Introduction: The Pan-Eurasian Experiment (PEEX) - multidisciplinary, multiscale and multicomponent research and capacity-building initiative. - Atmospheric Chemistry and Physics, 15, 13085-13096.

Kulmala, M., Nieminen, T., Nikandrova, A., Lehtipalo, K., Manninen, H.E., Kajos, M.K., Kolari, P., Lauri, A., Petäjä, T., Krejci, R., Hansson, H.-C., Swietlicki, E., Lindroth, A., Christensen, T.R., Arneth, A., Hari, P., Bäck, J., Vesala, T., Kerminen, V.-M. 2014b. $\mathrm{CO}_{2}$-induced terrestrial climate feedback mechanism: From carbon sink to aerosol source and back. - Boreal Environment Research, $19,122-131$.

Kulmala, M., Riipinen, I., Sipila, M., Manninen, H.E., Petaja, T., Junninen, H., Maso, M.D., Mordas, G., Mirme, A., Vana, M., Hirsikko, A., Laakso, L., Harrison, R.M., Hanson, I., Leung, C., Lehtinen, K.E.J., Kerminen, V.-M. 2007. Toward Direct Measurement of Atmospheric Nucleation. - Science, 318, 89-92.

Kulmala, M., Suni, T., Lehtinen, K.E.J., Dal Maso, M., Boy, M., Reissell, A., Rannik, Ü., Aalto, P., Keronen, P., Hakola, H., Bäck, J., Hoffmann, T., Vesala, T., Hari, P. 2004. A new feedback mechanism linking forests, aerosols, and climate. Atmospheric Chemistry and Physics, 4, 557-562.

Kulmala, M., Tammet, H. 2007. Finnish-Estonian air ion and aerosol workshops. - Boreal Environment Research, 12, 237-245.

Kulmala, M., Toivonene, A., Mäkelä, J.M., Laaksonen, A. 1998. Analysis of the growth of nucleation mode particles observed in Boreal forest. - Tellus B, 50, 449-462.

Kängsepp, V., Kangur, A., Kiviste, A. 2014. Tree Height Distribution in Young Naturally Regenerated Forests in Järvselja, Estonia. Local and Regional Challenges of Climate Change Adaptation and Green Technologies. - Polgár, A., Bazsó, T., Nagy, G., Gálos, B. (eds.). University of West Hungary Press, Sopron, 45-52.

Laakso, L., Anttila, T., Lehtinen, K.E.J., Aalto, P.P., Kulmala, M., Hõrrak, U., Paatero, J., Hanke, M., Arnold, F. 2004. Kinetic nucleation and ions in boreal forest particle formation events. - Atmospheric Chemistry and Physics, 4, 2353-2366.

Laan, B., Komsaare, K., Kaasik, M., Hõrrak, U. 2014. Estimating the origin of background aerosol pollution in Estonia. Proceedings of Abstracts 9th International Conference on Air Quality Science and Application: 9th International Conference on Air Quality Science and Application. - Mitto, T.,
Fallmann, J., Mikolajczyk, U., Suppan, P., Singh, V., Sokhi, R. (eds.). Garmisch-Partenkirchen, p. 247.

Leiner, M., Tamm, P. 2015. Estonian research infrastructures roadmap 2014. (Eesti teadustaristute teekaart 2014). Haridus- ja Teadusministeerium, Tartu. (In Estonian).

Lohmann, U., Feichter, J. 2005. Global indirect aerosol effects: a review. - Atmospheric Chemistry and Physics, 5, 715-737.

Luts, A., Hõrrak, U., Salm, J., Vana, M., Tammet, H. 2015. A Method for Automated Estimation of Parameters Controlling Aerosol New Particle Formation. - Aerosol and Air Quality Research, 15, 1166-1177.

Magill, A.H., Aber, J.D., Currie, W.S., Nadelhoffer, K.J., Martin, M.E., McDowell, W.H., Melillo, J.M., Steudler, P. 2004. Ecosystem response to 15 years of chron ic nitrogen additions at the Harvard Forest LTER, Massachusetts, USA. - Forest Ecology and Management, 196, 7-28.

Mahowald, N. 2011. Aerosol Indirect Effect on Biogeochemical Cycles and Climate. - Science, 334, 794-796.

Manninen, H.E., Nieminen, T., Asmi, E., Gagné, S., Häkkinen, S., Lehtipalo, K., Aalto, P., Vana, M., Mirme, A., Mirme, S., Hõrrak, U., Plass-Dülmer, C., Stange, G., Kiss, G., Hoffer, A., Törő, N., Moerman, M., Henzing, B., de Leeuw, G., Brinkenberg, M., Kouvarakis, G.N., Bougiatioti, A., Mihalopoulos, N., O'Dowd, C., Ceburnis, D., Arneth, A., Svenningsson, B., Swietlicki, E., Tarozzi, L., Decesari, S., Facchini, M.C., Birmili, W., Sonntag, A., Wiedensohler, A., Boulon, J., Sellegri, K., Laj, P., Gysel, M., Bukowiecki, N., Weingartner, E., Wehrle, G., Laaksonen, A., Hamed, A., Joutsensaari, J., Petäjä, T., Kerminen, V.-M., Kulmala, M. 2010. EUCAARI ion spectrometer measurements at 12 European sites - analysis of new particle formation events. - Atmospheric Chemistry and Physics, 10, 7907-7927.

Metzger, A., Verheggen, B., Dommen, J., Duplissy, J., Prevot, A.S.H., Weingartner, E., Riipinen, I., Kulmala, M., Spracklen, D. V, Carslaw, K.S., Baltensperger, U. 2010. Evidence for the role of organics in aerosol particle formation under atmospheric conditions. - Proceedings of the National Academy of Sciences of the United States of America, 107, 6646-6651.

Mirme, S., Mirme, A. 2013. The mathematical principles and design of the NAIS - a spectrometer for the measurement of cluster ion and nanometer aerosol size distributions. - Atmospheric Measurement Techniques, 6, 1061-1071.

Mäkelä, J.M., Aalto, P., Jokinen, V., Pohja, T., Nissinen, A., Palmroth, S., Markkanen, T., Seitsonen, K., Lihavainen, H., Kulmala, M. 1997. Observations of ultrafine aerosol particle formation and growth in boreal forest. - Geophysical Research Letters, 24, 1219-1222. 
Nieminen, T., Asmi, A., Dal Maso, M., Aalto, P.P., Keronen, P., Petäjä, T., Kulmala, M., Kerminen, V.-M. 2014. Trends in atmospheric new particle formation: 16 years of observations in boreal forest environment. - Boreal Environment Research, 19B, 191-214.

Niinemets, U., Bilger, W., Kull, O., Tenhunen, J.D. 1998. Acclimation to high irradiance in temperate deciduous trees in the field: changes in xanthophyll cycle pool size and in photosynthetic capacity along a canopy light gradient. - Plant, Cell and Environment, 21, 1205-1218.

Niinemets, U., Bilger, W., Kull, O., Tenhunen, J.D. 1999a. Responses of foliar photosynthetic electron transport, pigment stoichiometry, and stomatal conductance to interacting environmental factors in a mixed species forest canopy. - Tree Physiology, 19, 839-852.

Niinemets, Ü., Ciccioli, P., Noe, S.M., Reichstein, M. 2013. Scaling BVOC Emissions from Leaf to Canopy and Landscape: How Different Are Predictions Based on Contrasting Emission Algorithms? Biology, Controls and Models of Tree Volatile Organic Compound Emissions Tree Physiology. Niinemets, Ü., Monson, R.K. (eds.). Springer Netherlands, Dordrecht, 357-390.

Niinemets, Ü., Sõber, A., Kull, O., Hartung, W., Tenhunen, J.D. 1999b. Apparent Controls on Leaf Conductance by Soil Water Availability and via Light-Acclimation of Foliage Structural and Physiological Properties in a Mixed Deciduous, Temperate Forest. - International Journal of Plant Science, 160, 707-721.

Noe, S.M., Hüve, K., Niinemets, Ü., Copolovici, L. 2012. Seasonal variation in vertical volatile compounds air concentrations within a remote hemiboreal mixed forest. - Atmospheric Chemistry and Physics, 12, 3909-3926.

Noe, S.M., Kimmel, V., Hüve, K., Copolovici, L., Portillo-Estrada, M., Püttsepp, Ü., Jõgiste, K., Niinemets, Ü., Hörtnagl, L., Wohlfahrt, G. 2011. Ecosystem-scale biosphere-atmosphere interactions of a hemiboreal mixed forest stand at Järvselja, Estonia. - Forest Ecology and Management, 262, 71-81.

Noe, S.M., Krasnov, D., Krasnova, A., Cordey, H.P.E., Niinemets, Ü. 2016. Seasonal variation and characterisation of reactive trace gas mixing ratios over a hemiboreal mixed forest site in Estonia. Boreal Environment Research, 21, in press.

Paasonen, P., Asmi, A., Petäjä, T., Kajos, M.K., Äijälä, M., Junninen, H., Holst, T., Abbatt, J.P.D., Arneth, A., Birmili, W., van der Gon, H.D., Hamed, A., Hoffer, A., Laakso, L., Laaksonen, A., Richard Leaitch, W., Plass-Dülmer, C., Pryor, S.C., Räisänen, P., Swietlicki, E., Wiedensohler, A., Worsnop, D.R., Kerminen, V.-M., Kulmala, M. 2013. Warming-induced increase in aerosol number concentration likely to moderate climate change. - Nature Geoscience, 6, 438-442.
Petäjä, T., Mauldin III, R.L., Kosciuch, E., McGrath, J., Nieminen, T., Paasonen, P., Boy, M., Adamov, A., Kotiaho, T., Kulmala, M. 2009. Sulfuric acid and $\mathrm{OH}$ concentrations in a boreal forest site. - Atmospheric Chemistry and Physics, 9, 7435-7448.

Pihlatie, M.K., Christiansen, J.R., Aaltonen, H., Korhonen, J.F.J., Nordbo, A., Rasilo, T., Benanti, G., Giebels, M., Helmy, M., Sheehy, J., Jones, S., Juszczak, R., Klefoth, R., Lobo-do-Vale, R., Rosa, A.P., Schreiber, P., Serça, D., Vicca, S., Wolf, B., Pumpanen, J. 2013. Comparison of static chambers to measure CH4 emissions from soils. - Agricultural and Forest Meteorology, 171-172, 124-136.

Pilegaard, K. 2013. Processes regulating nitric oxide emissions from soils. - Philosophical Transactions of the Royal Society B: Biological Sciences, $368,20130126$.

Pusede, S.E., Cohen, R.C. 2012. On the observed response of ozone to NOx and VOC reactivity reductions in San Joaquin Valley California 1995present. - Atmospheric Chemistry and Physics, $12,8323-8339$.

Riccobono, F., Schobesberger, S., Scott, C.E., Dommen, J., Ortega, I.K., Rondo, L., Almeida, J., Amorim, A., Bianchi, F., Breitenlechner, M., David, A., Downard, A., Dunne, E.M., Duplissy, J., Ehrhart, S., Flagan, R.C., Franchin, A., Hansel, A., Junninen, H., Kajos, M., Keskinen, H., Kupc, A., Kurten, A., Kvashin, A.N., Laaksonen, A., Lehtipalo, K., Makhmutov, V., Mathot, S., Nieminen, T., Onnela, A., Petaja, T., Praplan, A.P., Santos, F.D., Schallhart, S., Seinfeld, J.H., Sipila, M., Spracklen, D. V., Stozhkov, Y., Stratmann, F., Tome, A., Tsagkogeorgas, G., Vaattovaara, P., Viisanen, Y., Vrtala, A., Wagner, P.E., Weingartner, E., Wex, H., Wimmer, D., Carslaw, K.S., Curtius, J., Donahue, N.M., Kirkby, J., Kulmala, M., Worsnop, D.R., Baltensperger, U. 2014. Oxidation Products of Biogenic Emissions Contribute to Nucleation of Atmospheric Particles. - Science, 344, 717-721.

Ross, J., Stenberg, P., Berninger, F., Hari, P. 1996. The influence of shoot architecture on photosynthesis. Production process of Scots pine: geographical variation and models. - Hari, P., Ross, J., Mecke, M. (eds.). Finnish Society of Forest Science - Finnish Forest Research Institute, Helsinki, 33-38.

Salminen, R., Nilson, T., Hari, P., Kaipiainen, L., Ross, J. 1983. A Comparison of Different Methods for Measuring the Canopy Light Regime. - Journal of Applied Ecology, 20, 897-904.

Siim, K., Kangur, A. 2013. Cultural Heritage in Järvselja. (Järvselja pärandkultuuri radadel). Kusmin, J., Kusmin, T. (eds.). Tartu, Eesti Loodusfoto OÜ. EMÜ metsandus- ja maaehitusinstituudi toimetised, 39, 139 pp. (In Estonian).

Smolander, S., He, Q., Mogensen, D., Zhou, L., Bäck, J., Ruuskanen, T., Noe, S., Guenther, A., Aaltonen, H., Kulmala, M., Boy, M. 2014. Comparing three vegetation monoterpene emission models 
to measured gas concentrations with a model of meteorology, air chemistry and chemical transport. - Biogeosciences, 11, 5425-5443.

Spracklen, D.V, Bonn, B., Carslaw, K.S. 2008. Boreal forests, aerosols and the impacts on clouds and climate. - Philosophical transactions. Series A, Mathematical, Physical and Engineering sciences, 366, 4613-4626.

Stocker, T.F., Qin, D., Plattner, G.-K., Alexander, L.V., Allen, S.K., Bindoff, N.L., Bréon, F.-M., Church, J.A., Cubasch, U., Emori, S., Forster, P., Friedlingstein, P., Gillett, N., Gregory, J.M., Hartmann, D.L., Jansen, E., Kirtman, B., Knutti, R., Krishna Kumar, K., Lemke, P., Marotzke, J., MassonDelmotte, V., Meehl, G.A., Mokhov, I.I., Piao, S., Ramaswamy, V., Randall, D., Rhein, M., Rojas, M., Sabine, C., Shindell, D., Talley, L.D., D.G., V., Xie, S.-P. 2013. Technical Summary. - Stocker, T.F., Qin, D., Plattner, G.-K., Tignor, M., Allen, S.K., Boschung, J., Nauels, A., Xia, Y., Bex, V., Midgley, P.M. (eds.). Climate Change 2013: The Physical Science Basis. Contribution of Working Group I to the Fifth Assessment Report of the Intergovernmental Panel on Climate Change. Climate Change 2013, Cambridge University Press, Cambridge, United Kingdom and New York, NY, USA.

Tammet, H., Komsaare, K., Hõrrak, U. 2013. Estimating neutral nanoparticle steady-state size distribution and growth according to measurements of intermediate air ions. - Atmospheric Chemistry and Physics, 13, 9597-9603.

Tammet, H., Komsaare, K., Hõrrak, U. 2014. Intermediate ions in the atmosphere. - Atmospheric Research, 135-136, 263-273.
Tammet, H., Mirme, A., Tamm, E. 2002. Electrical aerosol spectrometer of Tartu University. - Atmospheric Research, 62, 315-324.

Vanhanen, J., Mikkilä, J., Lehtipalo, K., Sipilä, M., Manninen, H.E., Siivola, E., Petäjä, T., Kulmala, M. 2011. Particle Size Magnifier for Nano-CN Detection. - Aerosol Science and Technology.

Vesala, T., Haataja, J., Aalto, P., Altimir, N., Buzorius, G., Garam, E., Hämeri, K., Ilvesniemi, H., Jokinen, V., Keronen, P., Lahti, T., Markkanen, T., Mäkelä, J.M., Nikinmaa, E., Palmroth, S., Palva, L., Pohja, T., Pumpanen, J., Rannik, Ü., Siivola, E., Ylitalo, H., Hari, P., Kulmala, M. 1998. Long-term field measurements of atmosphere-surface interactions in boreal forest combining forest ecology, micrometeorology, aerosol physics and atmospheric chemistry. - Trends in Heat, Mass and Momentum Transfer, 4, 17-35.

Westervelt, D.M., Pierce, J.R., Adams, P.J. 2014. Analysis of feedbacks between nucleation rate, survival probability and cloud condensation nuclei formation. - Atmospheric Chemistry and Physics, 14, 5577-5597.

Yu, H., Kaufman, Y.J., Chin, M., Feingold, G., Remer, L.A., Anderson, T.L., Balkanski, Y., Bellouin, N., Boucher, O., Christopher, S., DeCola, P., Kahn, R., Koch, D., Loeb, N., Reddy, M.S., Schulz, M., Takemura, T., Zhou, M. 2006. A review of measurement-based assessments of the aerosol direct radiative effect and forcing. - Atmospheric Chemistry and Physics, 6, 613-666. 


\section{Supplemental material}

Table S1. Atmospheric measurements conducted at the SMEAR Estonia station since 2012. The station uses two locations: Liispõllu (24 m high scaffold tower and small cottage) and Apna (130 m high mast, two $30 \mathrm{~m}$ high scaffold towers, main building and aerosol cottage).

Tabel S1. SMEAR Eesti mõõtejaamas tehtud atmosfäärimõõtmised alates 2012 aastast. Mõõtmised on seniajani toimunud peamiselt kahes asukohas: Liispõllu mõõtealal (24 meetri kõrgune tellingutorn ja mõõtemajake) ning Apna mõõtealal (130 meetri kõrgune mast ja kaks 30 m kõrgust masti, jaama põhimaja ja aerosoolide majake).

\begin{tabular}{|c|c|c|c|}
\hline $\begin{array}{l}\text { Measurement / } \\
\text { Mõõdetav tunnus }\end{array}$ & $\begin{array}{l}\text { Used device / } \\
\text { Kasutatavad seadmed }\end{array}$ & $\begin{array}{l}\text { Location / } \\
\text { Mõõtekoht }\end{array}$ & $\begin{array}{l}\text { Measurement period / } \\
\text { Mõoteperiood }\end{array}$ \\
\hline \multicolumn{4}{|c|}{ Greenhouse gases / Kasvuhoonegaasid } \\
\hline $\mathrm{CO}_{2}, \mathrm{CO}, \mathrm{H}_{2} \mathrm{O}, \mathrm{CH}_{4}$ & Picarro G2401 & $\begin{array}{l}\text { Liispõllu / } 2 \mathrm{~m} \\
\text { Apna / } 2 \mathrm{~m}\end{array}$ & $\begin{array}{l}07 / 2012-09 / 2013 \\
10 / 2013-02 / 2014\end{array}$ \\
\hline $\mathrm{CO}_{2}, \mathrm{H}_{2} \mathrm{O}$ & LiCor LI-7200 & Apna / 30,70 m & since $04 / 2014$ \\
\hline $\mathrm{CO}_{2}, \mathrm{H}_{2} \mathrm{O}, \mathrm{CH}_{4}$ & LGR GGA & Apna / 30,50,70,90,110 m & since $11 / 2015$ \\
\hline \multicolumn{4}{|c|}{ Fluxes / Voogude mõõtmine } \\
\hline $\mathrm{CO}_{2}, \mathrm{H}_{2} \mathrm{O}$ & $\begin{array}{l}\text { METEK uSonic-3 Class A } \\
\text { Licor LI-7200 }\end{array}$ & Apna / 30,70 m & since $04 / 2014$ \\
\hline \multicolumn{4}{|c|}{ Atmospheric trace gases / Atmosfääri lisandgaasid } \\
\hline $\mathrm{O}_{3}$ & Thermo Scientific $49 i$ & $\begin{array}{l}\text { Liispõllu / } 2 \mathrm{~m} \\
\text { Apna / } 2 \mathrm{~m} \\
\text { Apna / } 30 \mathrm{~m} \\
\text { Apna / 50,70,90,110 m }\end{array}$ & $\begin{array}{l}07 / 2012-09 / 2013 \\
10 / 2013-01 / 2015 \\
\text { since 01/2015 } \\
\text { since 08/2015 }\end{array}$ \\
\hline $\mathrm{SO}_{2}$ & Thermo Scientific 43i-TLE & $\begin{array}{l}\text { Apna / } 2 \mathrm{~m} \\
\text { Apna / } 30 \mathrm{~m} \\
\text { Apna / 50,70,90,110 m }\end{array}$ & $\begin{array}{l}10 / 2013-01 / 2015 \\
\text { since } 01 / 2015 \\
\text { since } 08 / 2015\end{array}$ \\
\hline $\mathrm{NO}_{\mathrm{x}}$ & Thermo Scientific $42 \mathrm{i}-\mathrm{TL}$ & $\begin{array}{l}\text { Liispõllu / } 2 \mathrm{~m} \\
\text { Apna / } 2 \mathrm{~m} \\
\text { Apna / } 30 \mathrm{~m} \\
\text { Apna / 50,70,90,110 m }\end{array}$ & $\begin{array}{l}07 / 2012-09 / 2013 \\
10 / 2013-01 / 2015 \\
\text { since } 01 / 2015 \\
\text { since } 08 / 2015 \\
\end{array}$ \\
\hline \multicolumn{4}{|c|}{ Meteorology / Meteoroloogilised mõõtmised } \\
\hline Turbulence & METEK uSonic-3 Class A & Apna / 30,50,70,90,110 m & since $04 / 2014$ \\
\hline Temperature & METEK PT-100 & Apna / 30,50,70,90,110 m & since $05 / 2015$ \\
\hline Pressure & METEK humidity sensor & Apna / 50 m & since $05 / 2015$ \\
\hline $\begin{array}{l}\text { Temp., pressure, rel. } \\
\text { humidity, precipitation }\end{array}$ & Vaisala WXT520 & Apna / 2 m & since $05 / 2014$ \\
\hline \multicolumn{4}{|c|}{ Radiation / Kiirgusmõõtmised } \\
\hline Total radiation & Delta-T Pyranometer & Apna / 40 m & since $06 / 2015$ \\
\hline $\begin{array}{l}\text { Aerosol particles and } \\
\text { air ions }\end{array}$ & Delta-T Pyranometer & Apna / $40 \mathrm{~m}$ & since $06 / 2015$ \\
\hline \multicolumn{4}{|c|}{ Aerosol particles and air ions / Aerosoolid ja aeroioonid } \\
\hline \multicolumn{4}{|c|}{ Air ion mobility distribution / Aeroioonide liikuvusjaotus } \\
\hline $\begin{array}{l}3.2 \text { to } 0.0013 \mathrm{~cm}^{2} \mathrm{~V}^{-1} \mathrm{~s}^{-1} \\
\text { ( } 0.8 \text { to } 40 \mathrm{~nm} \text { size } \\
\text { equivalent) and nano- } \\
\text { particle size distribu- } \\
\text { tions: } \sim 2 \text { to } 40 \mathrm{~nm}\end{array}$ & $\begin{array}{l}\text { Nano-aerosol and Air Ion } \\
\text { Spectrometer (NAIS) }\end{array}$ & $\begin{array}{l}\text { Liispõllu / } 2 \mathrm{~m} \\
\text { Apna aerosol cottage / } 2 \mathrm{~m} \\
\text { Liispõllu / } 24 \mathrm{~m} \\
\text { Apna scaffold tower / } 30 \mathrm{~m}\end{array}$ & $\begin{array}{l}11 / 2010 \\
06 / 2012-09 / 2015 \\
\text { since } 09 / 2015 \\
04 / 2014-09 / 2015 \\
\text { since } 10 / 2015\end{array}$ \\
\hline $\begin{array}{l}3.2 \text { to } 0.032 \mathrm{~cm}^{2} \mathrm{~V}^{-1} \mathrm{~s}^{-1} \\
\text { ( } 0.4 \text { to } 7.5 \mathrm{~nm} \text { size } \\
\text { equivalent) }\end{array}$ & $\begin{array}{l}\text { Balanced Scanning Mobility } \\
\text { Analyzer (BSMA) }\end{array}$ & Liispõllu / 2 m & $\begin{array}{l}08 / 2008 \\
09 / 2009\end{array}$ \\
\hline
\end{tabular}




\begin{tabular}{llll}
\hline Measurement / & Used device / & Location / & Measurement period / \\
Mõõdetav tunnus & Kasutatavad seadmed & Mõotekoht & Mõoteperiood
\end{tabular}

\section{Aerosol particle size distribution / Aerosoolide suurusjaotus}

$3 \mathrm{~nm}-10 \mu \mathrm{m}$

$10-1000 \mathrm{~nm}$ )

$0.5-20 \mu \mathrm{m}$

$5-500 \mathrm{~nm}$

$0.3-10 \mu \mathrm{m}$
Electrical Aerosol Spectrometer (EAS)

Scanning Mobility Particle Sizer (SMPS 3938), TSI Inc Aerodynamic Particle Sizer (APS 3321), TSI Inc.

Fast Mobility Particle Sizer (FMPS, TSI 3091) TSI Inc. Optical Particle Sizer (OPS, TSI 3330) TSI Inc.
Liispõllu / 2 m

$08 / 2008$

$09 / 2009$

$10 / 2010-11 / 201$

$06 / 2012-09 / 2015$

Apna aerosol cottage / $2 \mathrm{~m}$

since $09 / 2015$

Apna aerosol cottage / $5 \mathrm{~m}$

starting 2016

Apna aerosol cottage / $5 \mathrm{~m}$

starting 2016

Apna scaffold tower / 30 m

starting 2016

Apna scaffold tower / 30 m

starting 2016

\section{Air ionization / Õhu ionisatsioon}

Radon activity concentration

Gamma radiation
Radon Monitor AlphaGuard, 2 - $2.000 .000 \mathrm{~Bq} / \mathrm{m}^{3}$ Gamma radiation monitor GammaTRACER - XL2-3
Apna aerosol cottage / $2 \mathrm{~m}$

Apna aerosol cottage / $1 \mathrm{~m}$

starting 2016

starting 2016

since $10 / 2015$

Apna scaffold tower / 30 m

Micrometrology / Mikrometeroloogilised mõõtmised

3D-Wind speed and

METEK uSonic-3 Class A 
Table S2. Measurement of the forest ecosystem on the level branches, trees and whole forest stands, conducted at the different measurement sites (Liispõllu and Apna) at the SMEAR Estonia station.

Tabel S2. Metsaökosüsteemi kirjeldamiseks erinevatel tasemetel ja skaalal (alustades üksikpuu üksikutest osktest kuni puistutasemeni: tehtavad mõõtmised SMEAR Eesti mõlemal uurimisalal (Liispõllu ja Apna).

\begin{tabular}{|c|c|c|c|}
\hline $\begin{array}{l}\text { Measurement / } \\
\text { Mõõdetav tunnus }\end{array}$ & $\begin{array}{l}\text { Used device / } \\
\text { Kasutatavad seadmed }\end{array}$ & $\begin{array}{l}\text { Location / } \\
\text { Mõotekoht }\end{array}$ & $\begin{array}{l}\text { Measurement period / } \\
\text { Mõoteperiood }\end{array}$ \\
\hline \multicolumn{4}{|c|}{ Tree measurements / Üksikpuu mõõtmised } \\
\hline $\begin{array}{l}\text { Gas exchange, } \\
\text { photosynthesis }\end{array}$ & Branch chamber & $\begin{array}{l}\text { Apna / several heights } \\
\text { Pine/Spruce and Birch/Aspen }\end{array}$ & starting 2016 \\
\hline VOC & Branch chamber & Liispõllu / several heights & episodes since 2010 \\
\hline PAR & LiCor PAR-sensors & Apna / several heights & starting 2016 \\
\hline Radial increment & Dendrometer & $\begin{array}{l}\text { Liispõllu / Spruce, Birch } \\
\text { Apna / Pine, Spruce, Birch, } \\
\text { Aspen }\end{array}$ & $\begin{array}{l}\text { since } 11 / 2014 \\
\text { since } 5 / 2015\end{array}$ \\
\hline \multicolumn{4}{|c|}{ Single tree and stand level / Üksikpuu ja puistu tase } \\
\hline $\begin{array}{l}\text { Live and dead trees, } \\
\text { snags, lying woody } \\
\text { debris species and } \\
\text { composition, spatial } \\
\text { distribution, } \\
\text { DBH, height live } \\
\text { canopy height }\end{array}$ & FIELDMAP light set & $\begin{array}{l}\text { Liispõllu / } 5 \text { plots } \\
\text { Apna / } 21 \text { plots }\end{array}$ & $\begin{array}{l}\text { since } 8 / 2008 \\
\text { since } 7 / 2012\end{array}$ \\
\hline
\end{tabular}


Table S3. Soil measurements conducted at different sites of the SMEAR Estonia station, which play an important part of forest ecosystem investigation in Järvselja.

Tabel S3. SMEAR Eesti mõõtejaama juures erinevates asukohtades läbi vïdavad mullamõõtmised, mis omavad väga olulist rolli metsaökosüsteemi protsesside uurimise juures Järvseljal.

\begin{tabular}{|c|c|c|c|}
\hline $\begin{array}{l}\text { Measurement / } \\
\text { Mõodetav tunnus }\end{array}$ & $\begin{array}{l}\text { Used device / } \\
\text { Kasutatavad seadmed }\end{array}$ & $\begin{array}{l}\text { Location / } \\
\text { Mõotekoht }\end{array}$ & $\begin{array}{l}\text { Measurement period / } \\
\text { Mõõteperiood }\end{array}$ \\
\hline \multicolumn{4}{|c|}{ Soil measurements / Mulla mõõtmised } \\
\hline \multirow[t]{3}{*}{ Soil respiration } & Manual chamber (flask) & Liispõllu & $2008-2010$ \\
\hline & Manual chamber (GMP343) & Apna & since $05 / 2015$ \\
\hline & ACE & Liispõllu & $2009-2015$ \\
\hline Soil $\mathrm{CH}_{4}$ & Manual chamber (flask) & Liispõllu & $2008-2009$ \\
\hline Soil $\mathrm{NO}_{2}$ & Manual chamber (flask) & Liispõllu & $2008-2009$ \\
\hline \multirow{2}{*}{$\begin{array}{l}\text { Soil moisture and } \\
\text { temperature }\end{array}$} & Campaign measurements & Liispõllu & $2008-2009$ \\
\hline & Periodical measurements & Apna & $05 / 2015-10 / 2015$ \\
\hline \multicolumn{4}{|c|}{ Belowground biomass / Maaaluse biomassi mõotmised } \\
\hline & & Liispõllu & $2011-2015$ \\
\hline & & Apna & $2011-2015$ \\
\hline \multicolumn{4}{|c|}{ Soil physical and chemical characteristic / Mulla füüsikalised ja keemilised tunnused } \\
\hline \multirow{2}{*}{\multicolumn{2}{|c|}{$\begin{array}{l}\text { Soil organic and inorganic } \mathrm{N} \text { pools (Dissolved } \\
\text { Organic Nitrogen }[\mathrm{DON}] \text {, microbial biomass-N }[\mathrm{MB}-\mathrm{N}] \text {, } \\
\text { ammonium }\left[\mathrm{NH}_{4}^{+}\right] \text {and nitrate }\left[\mathrm{NO}_{3}^{-}\right] \text {), phenols, pentoses, } \\
\text { proteins, aminoacids, aromatic } \\
\text { compounds }\end{array}$}} & Liispõllu & Autumn 2012 \\
\hline & & Apna & Autumn 2012 \\
\hline \multicolumn{2}{|l|}{ Nutrients } & $\begin{array}{l}\text { Liispõllu } \\
\text { Apna }\end{array}$ & \\
\hline \multicolumn{2}{|l|}{$\mathrm{pH}$} & $\begin{array}{l}\text { Liispõllu } \\
\text { Apna }\end{array}$ & \\
\hline \multicolumn{2}{|l|}{ Bulk density } & $\begin{array}{l}\text { Liispõllu } \\
\text { Apna }\end{array}$ & \\
\hline \multicolumn{2}{|l|}{ Soil map } & $\begin{array}{l}\text { Liispõllu } \\
\text { Apna }\end{array}$ & \\
\hline \multicolumn{2}{|c|}{ 3D model of soil organic horizons and soil surface } & Apna & since 2014 \\
\hline
\end{tabular}




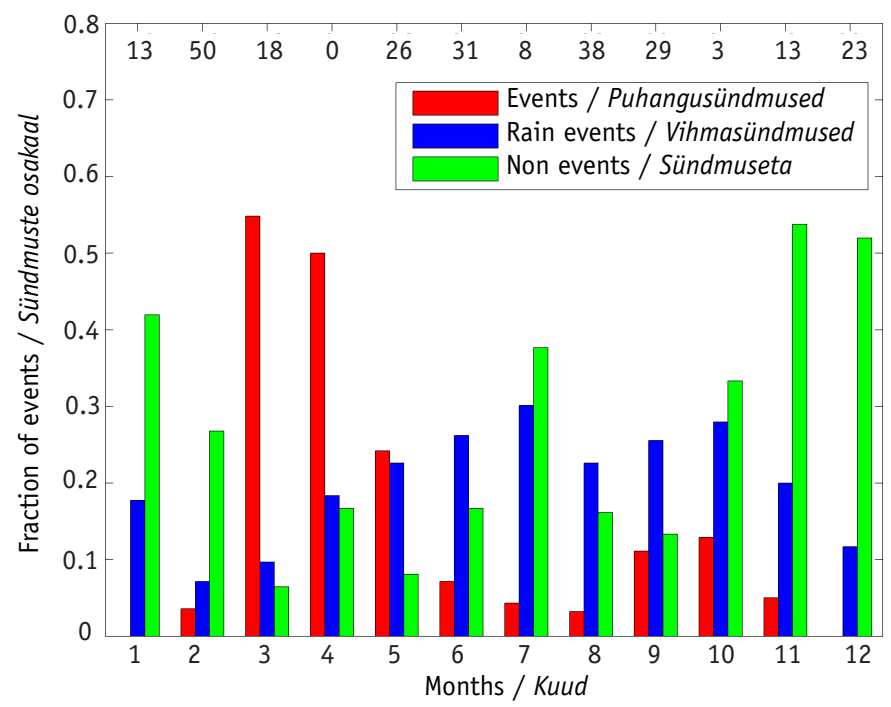

Figure S1. Statistics of new particle formation events recorded in 2014. Annual variation of nucleation burst events, non-events and rain induced events. Beside the NPF events also rain induced events of balloelectric intermediate air ions formation are shown. Fraction of event days from all measurement days in each month is indicated in vertical scale, numbers above show the missing data in \%.

Joonis S1. 2014 aastal mõõdetud atmosfääri aerosooli uute osakeste tekke statistika kuude lõikes. Nukleatsioonipuhangu ja mitte-puhangu päevade ning vihma poolt tekitatud balloelektriliste keskmiste õhuioonide puhangu päevade aastane käik. Vertikaalteljel on esitatud sündmuste suhteline jaotumine kuude lõikes ning ülemisel skaalal on esitatud puuduvate andmete osakaalud protsentidena. 


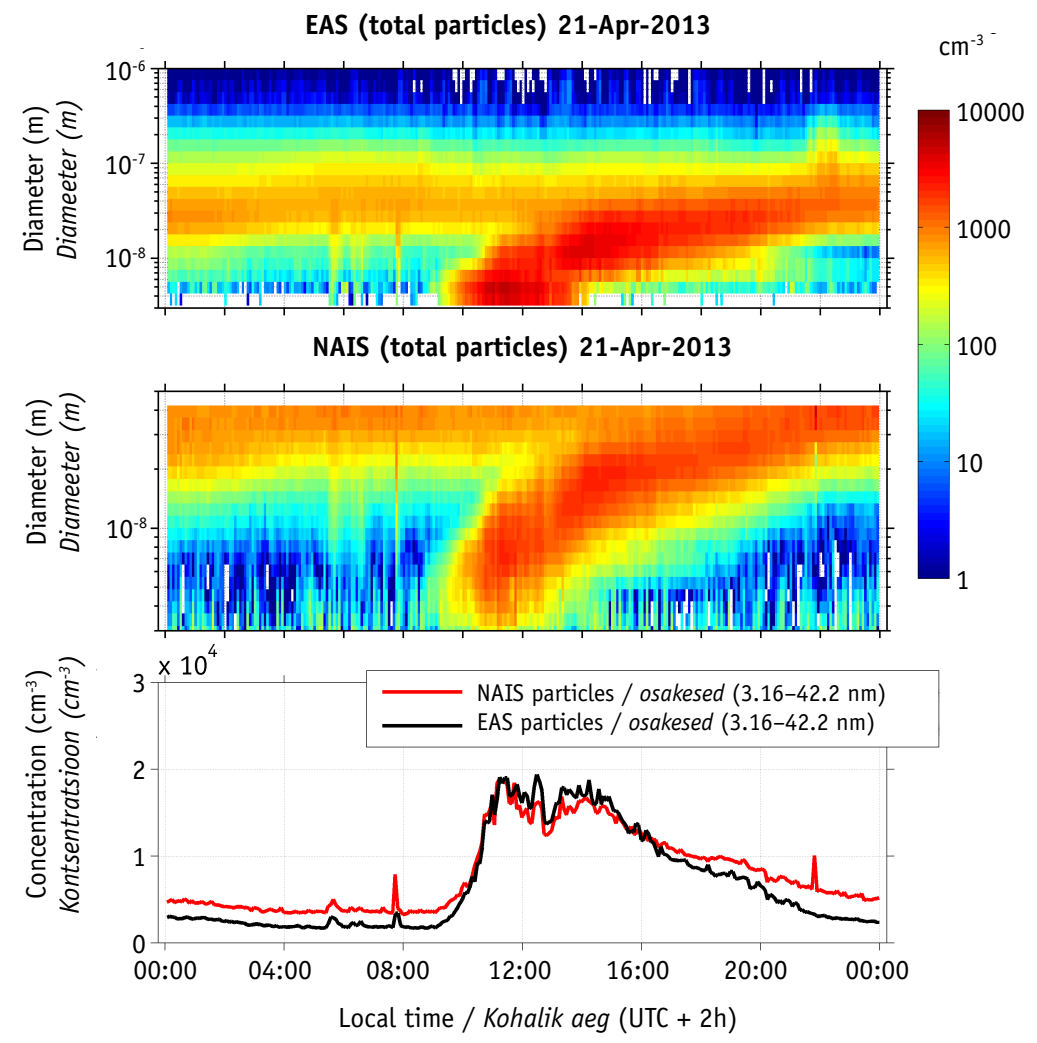

Figure S2. Dynamics of aerosol particle and air ion size distributions in the size range 3.2-42 nm during nucleation burst events measured by the spectrometers EAS and NAIS. Uppermost figure represents the EAS measurements, the following two surface plots represent the NAIS measurements of aerosol particles in two measuring regimes: with negative charging ("- charged particles") and with preliminary neutralization followed by negative charging ("- alternate charged particles"). The lowermost figure presents the time series of total concentrations of particles in the size range of 3.2-42 nm for the EAS and NAIS data. The event recorded on April 21, 2013 represents an example of a typical "Banana"-type nucleation event and the dynamic of secondary organic aerosol (SOA) growth measured by the spectrometers EAS and NAIS.

Joonis S2. Nukleatsioonipuhangute ajal spektromeetritega EAS ja NAIS mõõdetud aerosooliosakeste ja aeroioonide suurusjaotuste dünaamika suurusvahemikus 3,2-42 $\mathrm{nm}$. Kõige ülemine graafik esitab EAS abil mõõdetud suurusjaotuste ja kaks järgnevat NAIS abil kahes erinevas mõõterežiimis saadud tulemused. Kõige alumine graafik esitab spektromeetritega EAS ja NAIS mõõdetud aineosakeste suurusvahemiku 3,2-42 nm kogukontsentratsiooni ööpäevase käigu 21 aprilli 2013 aastal. 


\title{
SMEAR Eesti: suuremahulise ökosüsteemi ja atmosfääri vastastikmõjude mõõtmise teadus - infrastruktuuri perspektiivid
}

\author{
Steffen M. Noe, Ülo Niinemets, Alisa Krasnova, Dmitrii Krasnov, Azimeh Motallebi, \\ Vivika Kängsepp, Kalev Jõgiste, Urmas Hõrrak, Kaupo Komsaare, Sander Mirme, \\ Marko Vana, Hannes Tammet, Jaana Bäck, Timo Vesala, Markku Kulmala, \\ Tuukka Petäjä ja Ahto Kangur
}

\section{Kokkuvõte}

Pikaajalised komplekssed, kindla mõõteprotokolli ja suure mõõtetäpsusega andmed, mis võimaldavad kirjeldada ökosüsteemi ning atmosfääri vahelisi vastastikmõjusid erinevates troofilistes skaalades, on ainuke usaldusväärne viis mõistmaks globaalse muutumise ohtusid, aga ka võimalusi. Esimesed ökofüsioloogilised mastimõõtmised tehti Järvseljal juba 1995. aastal, kui paigaldati esimesed kaks võrasisest masti kase-haava segapuistusse (Niinemets et al. 1998, 1999a, b).

Vabas looduses metsaökosüsteemis toimuva energia ja ainevoo (peamiste reaktsioongaaside ning sealhulgas ka süsinikuvoo) põhjalikuks jälgimiseks on Helsingi Ülikooli teadlased valmis ehitanud SMEAR (Station for Measuring forest Ecosystem Atmosphere Relations) mõõtejaamad (Hari \& Kulmala, 2005). Soomes on neli jaama ning nende paigutus järgib põhja-lõunasuunalist gradienti. SMEAR Eesti mõõtejaam pikendab seda gradienti märgatavalt lõunasuunas. SMEAR põhimõtteid järgivaid ökosüsteem-atmosfäär terviku mõõtmisi on Eestis Järvseljal tehtud 2008. aastast alates (Noe et al., 2011; Bourtsoukidis et al., 2014). 2014. aastal sai valmis SMEAR Eesti mõõtejaama ehitus ja seadmestamine, jaam avati 23. augustil ning enamik mõõtmisi tehakse sellest ajast alates pidevalt. SMEAR Eesti mõõtejaamas on põhjanaabritest selgelt eristuv võrasisene lisatase (joonis 1), et saaks võimalikult täpselt kirjeldada Eesti hemiboreaalsetele metsade tihedast alusmetsast ja palju suuremast lehtpuu osakaalust tingitud erisust.
SMEAR Eesti mõõtejaam (58.2714 N, 27. 2703 E, $36 \mathrm{~m}$ a.s.1.) Eesti Maaülikooli Järvselja Õppe- ja Katsemetskonnas paikneb hemiboreaalses segametsade piirkonnas. Jaama ümbritseval neelualal on peamised puuliigid harilik mänd (Pinus sylvestris L.), harilik kuusk (Picea abies (L.) Karst.), arukask (Betula pendula Roth.), sookask (B. pubescens Ehrh.), sanglepp (Alnus glutinosa (L.) Gaertn.) ja harilik haab (Populus tremula L.). Metsale on omane struktuuri ja liigilise koosseisu suur heterogeensus, kusjuures valitsevas puurindes on domineeriv puuliik harilik mänd ning harilik kuusk ja lehtpuud esinevad kaaspuuliikidena või madalamates rinnetes. Mõõtejaama ümbruse puistud on valdavalt olnud majandatavad ning seetõttu puistute keskmised vanused varieeruvad alates kolmest aastast hiljutistel lageraiealadel kuni rohkem kui 200 aastat lähedal asuvates vanades loodusmetsades. Peamise puurinde keskmine kõrgus jaama vahetus läheduses on 21 meetrit, kuid jaamast 300 meetri raadiuses ulatub vanemate puistute keskmine kõrgus ka üle 35 meetri. Nii nagu metsas, on väga vahelduv ja varieeruv ka jaama ümbritsev muldkate - leidub erinevaid glei-, leet- ja leetunud muldi ning turbamuldi. Aasta keskmine temperatuur on $4-6{ }^{\circ} \mathrm{C}$ ja aastas tuleb 500-750 mm sademeid, millest 40-80 mm sajab lumena. Kasvuperioodi keskmine pikkus on 170-180 päeva ning jaama ôhukvaliteet vastab tüüpilise puhta õhuga tausttingimusele (Noe et al., 2011, 2012). 
SMEAR Eesti mõõtejaam jaguneb kahe uurimisala vahel: Apna peamine uurimisala ja Liispõllu esmane mõõteala. Apna uurimisalal (joonis 2) paiknevad peamised tugistruktuuri rajatised, nagu mõõtejaama maja, aerosoolimajake, parkla koos kuue teisaldatava konteinerjaama ühendusliidesega ning peamised mõõteobjektid 130-meetrine seadmemast ja kaks 30-meet- rist võramasti. Liispõllu mõõtealal paikneb 24-meetrine võramast ning seda toetav seadmemajake. Apna alal on püsiv internetiühendus ning elektriliidesed kuni 380 volti, Liispõllu alal on internetiühendus saavutatav GSM modemiga ning 220-voldine elektriühendus. Detailne ülevaade SMEAR Eesti mõõtejaama seadmestusest ja mõõteprotokollist on lisades 1-4. 